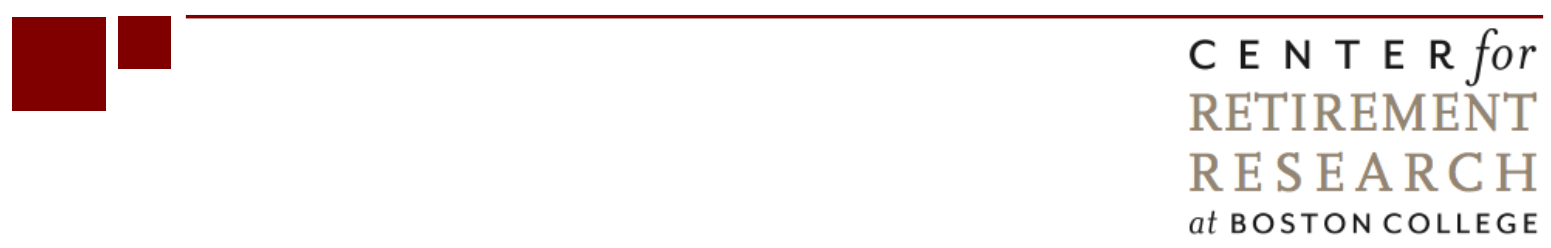

\title{
HOW DO THE CHANGING LABOR SUPPLY BEHAVIOR AND MARRIAGE PATTERNS OF WOMEN AFFECT SOCIAL SECURITY REPLACEMENT RATES?
}

\author{
April Yanyuan Wu, Nadia S. Karamcheva, Alicia H. Munnell, and Patrick Purcell
}

CRR WP 2013-16

Submitted: July 2013

Released: July 2013

\begin{abstract}
Center for Retirement Research at Boston College
Hovey House

140 Commonwealth Avenue

Chestnut Hill, MA 02467
\end{abstract}

Tel: 617-552-1762 Fax: 617-552-0191

http://crr.bc.edu

April Yanyuan Wu is a research economist at the Center for Retirement Research at Boston College (CRR). Nadia S. Karamcheva is a research associate at the Urban Institute. Alicia H. Munnell is the Peter F. Drucker Professor of Management Sciences at Boston College's Carroll School of Management and the director of the CRR. Patrick Purcell is researcher at the U.S. Social Security Administration (SSA). The research reported herein was pursuant to a grant from the SSA, funded as part of the Retirement Research Consortium (RRC). The findings and conclusions expressed are solely those of the authors and do not represent the views of SSA, any agency of the federal government, the RRC, the Urban Institute, or Boston College. The authors would like to thank Zhenya Karamcheva, Katherine Burnham, and Madeline Medenica for excellent research assistance. The authors would also like to thank Ben Bridges, Barbara A. Butrica, Irena Dushi, Melissa Favreault, Susan Grad, Alice M. Henriques, Virginia P. Reno, Karen E. Smith, Glenn Springstead, and Karen van der Wiel for their thoughtful comments and suggestions.

(C) 2013, April Yanyuan Wu, Nadia S. Karamcheva, Alicia H. Munnell, and Patrick Purcell. All rights reserved. Short sections of text, not to exceed two paragraphs, may be quoted without explicit permission provided that full credit, including $\odot$ notice, is given to the source. 


\begin{abstract}
About the Center for Retirement Research
The Center for Retirement Research at Boston College, part of a consortium that includes parallel centers at the University of Michigan and the National Bureau of Economic Research, was established in 1998 through a grant from the Social Security Administration. The Center's mission is to produce first-class research and forge a strong link between the academic community and decision-makers in the public and private sectors around an issue of critical importance to the nation's future. To achieve this mission, the Center sponsors a wide variety of research projects, transmits new findings to a broad audience, trains new scholars, and broadens access to valuable data sources.
\end{abstract}

Center for Retirement Research at Boston College

Hovey House

140 Commonwealth Avenue

Chestnut Hill, MA 02467

phone: 617-552-1762 fax: 617-552-0191

e-mail: crr@bc.edu

crr.bc.edu

Affiliated Institutions:

The Brookings Institution

Massachusetts Institute of Technology

Syracuse University

Urban Institute 


\begin{abstract}
This paper seeks to determine the impact of the changing lives of women - increased labor force participation/earnings and reduced marriage rates - on Social Security replacement rates. First, our estimates, based on the Health and Retirement Study and Modeling Income in the Near Term, show that Social Security replacement rates have dropped sharply at both the household- and individual-level, and the decline will continue for future retirees. Our second finding is that this aggregate change masks a complex relationship between replacement rates and the marital status and income levels of individuals. The decline in replacement rates over time is largest for married couples with husbands whose earnings are in the top tercile. Decomposing the reasons for the overall decline shows that increases in the labor supply and earnings of women explain more than one-third of the change. In contrast, the impact of changing marital patterns is relatively small. Much of the remaining explanation rests with the increased Full Retirement Age and changing claiming behaviors.
\end{abstract}




\section{Introduction}

The Social Security Trustees Report (U.S. Social Security Administration 2012a) states that replacement rates for the medium earner rose from about 30 percent in the 1970s to 40 percent in the 1980s, where they remain today. But replacement rates for individuals and households depend on more than Social Security provisions, they also depend on labor force activity and household arrangements.

While an extensive literature has explored how policy changes affect the Social Security program, only a few have focused on the impacts of demographic factors - importantly, the changing role of women. ${ }^{1}$ Compared to thirty years ago, women today have higher levels of education, increased labor force participation, more stable career trajectories and higher salaries, and a higher probability of being divorced or never married.

This paper explores how the changing lives of women affect Social Security replacement rates and thereby the program's finances. The analysis starts with trends in replacement rates for current retirees based on the Health and Retirement Study (HRS), which contains lifetime earnings profiles of actual workers and provides details of workers' demographics and marital status. It then uses the Modeling Income in the Near Term (MINT) microsimulation model to project changes in replacement rates for future cohorts. The paper extends previous studies in that it makes use of rich data sources to produce replacement rates across a broad range of cohorts: Depression Era (born 1931-41), War Baby (1942-47), Early Baby Boomers (1948-53), Middle Baby Boomers (1954-59), Late Baby Boomers (1960-65), and Generation X (1966-75). Moreover, information on actual workers makes it possible to examine changes in replacement rates within cohorts by marital status and by income distribution.

Further, the paper decomposes the reasons behind changes in the replacement rates into contributing factors, such as labor supply, marital patterns, and the extension of the Full Retirement Age (FRA) and Social Security claiming decisions, using a Blinder-Oaxacadecomposition method. This approach not only isolates the impact of the changing lives of women from other factors, but allows us to quantify how these sweeping changes in women's lives have contributed to the changes in replacement rates over time.

\footnotetext{
${ }^{1}$ Some recent examples include Butrica, Iams, and Sandell (1999), Butrica and Iams (2000), Favreault, Sammartino, and Steuerle (2002), and Iams et al. (2009). Earlier work includes U.S. Department of Health, Education, and Welfare (1979), Burkhauser and Holden, eds. (1982), Congressional Budget Office (1986), Ferber (1993), Harrington Meyer (1996), Ross and Upp (1993), and U.S. Department of Health and Human Services (1985).
} 
This paper focuses on replacement rates - benefits as a percent of pre-retirement earnings. As wages have risen over time, so have the level of Social Security benefits; therefore relative measures such as replacement rates, rather than absolute measures, are more appropriate when assessing the degree to which the program helps retirees maintain their standard of living in retirement. Of course, Social Security is only one component of retirement income, and therefore Social Security replacement rates alone do not provide a complete measure of retirement income adequacy. However, because Social Security is the largest source of retirement income for a majority of retirees, the Social Security replacement rate is an important measure of retirement income adequacy.

The paper proceeds as follows. Section 2 documents how women's roles have changed over time. It also presents a brief overview of prior studies. Section 3 describes the construction of the data and the methodology. Section 4 summarizes the trends in replacement rates across cohorts and within cohorts by marital status. Section 5 discusses the decomposition procedure to investigate how much the changing roles of women - characterized by both labor force activity and marital patterns - explain the differences in replacement rates across cohorts. The final section concludes.

The findings can be summarized as follows. First, the changing role of women has led to a marked decrease in the proportion of pre-retirement income Social Security replaces at both the household- and individual-level, and the decline will continue for future retirees. Second, changes at the aggregate level mask the more complex relationship by marital status. The change is relatively modest for the never married, but larger for married, divorced, and widowed households. And the decline in replacement rates for couples is largest for households with husbands' earnings in the top tercile. At the individual level, the decline in replacement rates is most dramatic for widows, and the decline is more pronounced for women than for men.

Third, the decomposition analysis shows that changes in labor force participation, including increased labor supply and earnings, account for more than a third of the difference in replacement rates between individuals born in the early 1930s and Generation Xers (born 1966 1975). While marital patterns have also changed dramatically over time, the impact of this factor is relatively small. However, differences in the FRA and claiming behaviors across cohorts also explain a significant fraction of the change in replacement rates. Nevertheless, up to 30 percent of the change across cohorts cannot be attributed to differences in mean characteristics identified 
in our analysis and remain 'unexplained.' These unexplained differences could be driven in part by the underlying assumptions used for the projection, as the explanatory power of the models is significantly higher for comparisons of cohorts who have already claimed Social Security benefits or will do so in the near future. As cohorts get further apart, the explanatory power of the models declines. ${ }^{2}$

\section{Background}

\section{Social Security Program}

Before exploring how women's labor force activity affects replacement rates, it is necessary to understand how Social Security benefits are determined. Social Security benefits, which over a third of beneficiaries aged 65 or older depend on for 90 percent or more of their total income, are programmatically linked to both earnings and marital histories (U.S. Social Security Administration, 2012b). Social Security pays retired-worker benefits to individuals who have accumulated 40 or more quarters of earnings in covered employment over their lives. Benefits at the FRA are the result of a three-step process. First, a worker's previous earnings are restated in terms of today's wages by indexing past earnings up to age 60 to wage growth. Second, indexed earnings for the highest 35 years are then averaged and divided by 12 to calculate Average Indexed Monthly Earnings (AIME). The final step is to calculate the Primary Insurance Amount (PIA), which is the sum of applying three separate percentages to portions of the AIME. The portions are determined by earnings thresholds - or "bend points" - that are indexed to wage growth, and thus depend on the year in which a person reaches age 62 . Specifically, for workers first becoming eligible for benefits in 2013, their PIA is the sum of:

- 90 percent of the worker's first $\$ 791$ of AIME, plus

- 32 percent of AIME between $\$ 791$ and $\$ 4,768$, plus

- 15 percent of any AIME in excess of $\$ 4,768$.

This PIA is recalculated as long as the individual remains employed; it is indexed to prices from age 62 . The benefit actually paid depends on when the worker claims. Benefits paid between age 62 and the FRA are actuarially reduced, and benefits paid between the FRA and 70 are actuarially increased.

\footnotetext{
${ }^{2}$ Results related to later cohorts are subject to the uncertainty associated with the projection and should be interpreted with caution.
} 
In addition to the worker's benefit, Social Security provides dependent benefits to qualified spouses of retired workers. While these benefits are not gender based, they typically go to women because women tend to work less and earn less than men. Thus, a wife is entitled to two types of benefits: 1) a spouse's benefit that will top up her own retirement benefit to 50 percent of her husband's PIA (unreduced for his early retirement); and 2) a survivor's benefit that will top up her own benefit to 100 percent of her husband's benefit (reduced for early retirement). Dependent divorced spouses are entitled to benefits if their marriage lasted at least 10 years. A person with a previous marriage that ended in widowhood is also eligible if the deceased spouse was fully insured.

When most people retired as married couples and most women did not work, it was straightforward to calculate replacement rates. The wife who claimed at her FRA was entitled to a benefit equal to 50 percent of her husband's (given that he also claimed at FRA), so if the replacement rate for the typical worker was 40 percent, the replacement rate for the couple would be 60 percent. As women went to work, the calculation became less obvious, since married women were entitled to the larger of the spouse's benefit or the benefit they could earn on their own. Further, over time, the share of women never-married or ever-divorced reaching retirement has increased and will continue to rise. The following section discusses changes in women's economic and social lives and their implications for Social Security replacement rates.

\section{Women's Economic and Social Lives: Striking Changes and Their Implications}

On virtually every dimension, women's economic and social lives have changed, and these changes are remaking the current and future profile of the U.S. retiree population. This section describes the changing role of women in two key dimensions: labor force participation and marital status.

\section{Labor market trends}

Women's labor force participation has risen dramatically over the last five decades. While only 37 percent of women age 20-64 worked in 1950, more than 71 percent worked by 2011. Figure 1 describes the labor force participation rate of women age 25-34 by birth cohort. For women of Generation X, 73 percent were in the labor force at age 25-34, more than twice the rate of women born in the early 1930s. 
This increase in labor force participation has occurred mostly among married women: between 1970 and 2010, the percentage of married women in the labor market rose from 40 percent to 61 percent (Kreider and Ellis 2011). By birth cohort, 34 percent of married women age 25-34 born in the early 1930s were in the labor force; the corresponding number for married women of Generation $\mathrm{X}$ is close to 70 percent (Figure 1).

Participation levels do not tell the whole story: type of occupation and pay scale are also important to fully understand how labor market trends affect the economic status of women. With respect to job type, women are moving away from lower paying jobs towards managerial and professional positions with higher wage rates. Currently, 40 percent of women are in managerial and professional jobs, compared to just 18 percent in 1975 (U.S. Department of Labor 2010).

The gender difference in wages has endured, but it is declining. Women who work full time are now earning 80 percent of the male wage compared to 62 percent in 1979 (U.S. Bureau of Labor Statistics 2008). Figure 2 describes the median ratio of the wife's to husband's AIME by cohort. Generation X wives are projected to earn about 68 percent of their husbands' lifetime earnings, which is 2.3 times the ratio for wives born in the early 1930s. As more women enter the labor force and women's earnings increase relative to their husbands' earnings, more women qualify for worker-only benefits. Similarly, the proportion of women receiving only spousal or widows' benefits will decline over time.

\section{Marriage trends}

Dramatic changes in family formation have occurred in the last four decades. Two family formation behaviors - marriage and divorce - are critical to determining Social Security outcomes and adequacy.

Marriage rates have fallen sharply over the past few decades. Figure 3 summarizes marriage trends for women by cohort and age. While 84 percent of women born in the early 1930s were married at age 25-34, the proportion declines to less than 60 percent for Generation Xers. While nearly 70 percent of women in the oldest cohort were married at ages 55-64, the number is projected to decline for Generation Xers to only about 56 percent. Along with changing marriage rates, the median age at first marriage has also increased from 20.3 in 1950 to 25.1 in 2000 (Kreider and Ellis 2011). 
Divorce rates increased rapidly from 1960, peaked in 1979, and have remained flat since the mid-1980s. Although the divorce rate has leveled off, the characteristics of divorce have been changing. In particular, the duration of marriages ending in divorce appears to have declined among more recent cohorts of women. Among first marriages, the share of those who remained married at their tenth anniversaries declined from 82.8 percent for those married in 1960-1964 to 74.5 percent for those married in 1990-1994 (Kreider and Ellis 2011).

As a result of trends in marriage, divorce, and marriage duration, a higher percentage of women are likely to enter retirement without having married or having been married only for a short time, which has important implications for their retirement security generally and their Social Security benefits specifically.

\section{Literature to Date}

While an extensive literature has explored how policy changes affect the Social Security program, only a few studies have focused on the impact of demographic factors - particularly the changing lives of women. Using MINT, Butrica, Iams, and Smith $(2007,2012)$ examine how sweeping demographic/economic changes, including rising educational attainment, changing marital patterns, changes in female and male labor force participation and earnings, and the increasing share of immigrants and minorities impact retirement income across generations. They find that total income replacement rates will decline and Baby Boomers and Generation Xers are less likely to have enough postretirement income to maintain their preretirement standard of living compared with current retirees.

A few studies have focused specifically on women. Butrica and Smith (2012a) explore the impact of women's increasing labor force participation and earnings on married women's Social Security benefits and find that the share of married women projected to receive spouses' benefits at retirement has declined in more recent birth cohorts. Although most wives will still be eligible for survivor benefits, the share ineligible is projected to double between cohorts. Using the Current Population Survey (CPS), Munnell, Sanzenbacher, and Soto (2007) evaluate the increased labor force participation of wives on the Social Security replacement rate of couples and find that, over the last forty years, the replacement rate for the hypothetic average couple has declined from 50 percent to 45 percent. 
Another strand of literature examines changes in marital patterns and the economic wellbeing of divorced women in retirement. For instance, Butrica and Smith (2012b) find that changes in women's earnings and work patterns along with marriage-duration trends result in more divorced women receiving retired-worker benefits based on their own earnings. However, those who do not meet the 10-year marriage requirement are projected to have low retirement income and high poverty rates.

The following analysis, which builds on the existing literature, has three goals. The first is to investigate how Social Security replacement rates have changed across a broad range of cohorts and within cohorts by marital status and by income. Second, the study aims to improve on estimates of the previous studies by using data from two different households surveys matched with administrative records. The third goal is to explain the extent to which the changing lives of women can explain the pattern of replacement rates across cohorts.

\section{Data and Methodology}

\section{Data}

For the analysis of current retirees, the data come from the HRS 1992 through 2010 waves, matched to the Social Security administrative earnings records, covered earnings from 1951 through $2008 .^{3}$ The HRS is a nationally representative longitudinal study of older Americans. The survey began in 1992 with an initial cohort of 12,652 individuals from 7,607 households in which at least one member was born between 1931 and 1941. Additional cohorts were added later. Individuals may consent to have their Social Security earnings histories linked to the survey and approximately 70 percent of respondents have done so. Our HRS sample is grouped into four birth cohorts: Depression Era 1 (Depression 1, 1931-1935), Depression Era 2 (Depression 2, 1936-1941), War Baby (WB, 1942-1947), and Early Baby Boomers (EBB, 19481953). ${ }^{4,5}$

\footnotetext{
${ }^{3}$ The matched administrative earning records will allow us to accurately calculate the replacement rates and avoid the reporting errors that are common in public use surveys.

${ }^{4}$ We did not include the Children of the Depression Era (CODA), born in the late 1920s. When we first observed individuals of the CODA cohort in 1998, they were 68-74 years old and about 40 percent were widowed. Because of the selection bias due to mortality, the replacement rate calculated using the HRS for the CODA cohort does not represent the replacement rate of all individuals born during this period. Further, for the majority of widows (widowers) of the CODA cohort, we do not have the information on their late spouses. Thus, we decided to exclude the CODA cohort from our analysis.
} 
To project the replacement rate for future retirees, we use MINT. MINT is a microsimulation model developed by the Social Security Administration. MINT links individuals' demographic information, marital histories, and information on income and wealth from the Survey of Income and Program Participation (SIPP) with their earnings and benefit histories from SSA administrative data. Based on these data, MINT projects each retiree's income from Social Security benefits, pensions, assets, and earnings (for working beneficiaries). ${ }^{6}$ Making use of MINT, we are able to project the changes in replacement rates for Middle Baby Boomers (MBB, 1954-1959), Late Baby Boomers (LBB, 1960-1965), and Generation X (Gen X, 1966-1975), cohorts where female labor force participation and marital patterns have changed most dramatically. MINT can be also used to estimate benefits for households that are already retired. ${ }^{7}$

\section{Replacement Rate Calculations}

In this study, the replacement rate is defined as the ratio of the unit's (person or household) Social Security benefit to their AIME. See later in this section for details. As discussed in Purcell (2012), there is no common means of measuring replacement rates. Whether a given replacement rate represents an adequate retirement income depends on whether the denominator in the replacement rate calculation is an appropriate measure of preretirement earnings. We use AIME in the replacement rate calculation rather than peak or final earnings because the AIME measures lifetime earnings and thus reflects available resources over individuals' careers from which they could reasonably accrue retirement income.

Estimating the replacement rate is a three-step process. The first step is to construct the lifetime earnings profile. The second step is to estimate Social Security benefits based on earnings and marital status. The third step is to calculate replacement rates at time of first benefit receipt, taking account of actuarial adjustments for early and late claiming.

\footnotetext{
${ }^{5}$ Since in our MINT sample, the Depression Era cohort is separated into two cohorts: Depression Era 1 (born between 1931 to 1935) and Depression Era 2 (born between 1936 and 1941) and they come from two versions of the MINT model-MINT5 and MINT6, we separate our HRS sample of the Depression Era into two groups as well to be consistent.

${ }^{6}$ For descriptions of versions 5 and 6 of MINT, see Smith et al. (2007, 2010, respectively).

${ }^{7}$ To ensure that our cohort estimates are representative, and to minimize survival bias, we use two versions of the MINT model - MINT 5 and MINT 6. Statistics related to the first half of the Depression Era cohort - the Depression Era 1 cohort (1931-1935) - in our analysis are derived from MINT 5, while the rest of the cohorts are extracted from MINT 6. MINT 5 derives data from the 1990 to 1996 SIPP, while MINT 6 uses the 2001 and 2004 panels of the SIPP.
} 


\section{Lifetime Earnings}

Lifetime earnings serve as a base for calculating career average indexed earnings and Social Security benefits. As noted, in the HRS, the administrative data provide Social Security earnings histories back to 1951 for the approximately 70 percent of the sample that has given permission to link. While previous work has documented that giving permission to link is nonrandom (Haider and Solon 2000), the distribution of Social Security benefits is similar across the linked and non-linked respondents (Kapteyn et al. 2006). Thus, for the approximately 30 percent of the HRS sample that has not given permission to link, we follow Gustman and Steinmeier (2001) and estimate earnings histories based on survey data on previous jobs and wages, using the estimated returns to tenure from Anderson, Gustman, and Steinmeier (1999). ${ }^{8}$

MINT projects each person's mortality, entry to and exit from Social Security Disability Insurance rolls, and age of first receipt of Social Security retirement benefits. For younger cohorts, MINT projects their income and characteristics into the future, adjusting for expected demographic and socioeconomic changes. Further, MINT accounts for major changes in the growth of economy-wide real earnings, the distribution of earnings both between and within birth cohorts, and the composition of the retiree population. Since MINT is designed to simulate the whole earnings profile, no additional simulation is needed.

\section{Social Security Benefits}

As discussed in Section 2, the Social Security PIA is calculated by applying a piecewiselinear formula to each worker's AIME. In computing the AIME using the HRS, earnings prior to age 60 are indexed by the average wage index for the year the individual attains age $60 .{ }^{9}$

\footnotetext{
${ }^{8}$ To project earnings beyond the year at which the individual last gave permission to match to the administrative data, we again follow Gustman and Steinmeier (2001). For individuals with self-reported earnings, the assumption is that the average of their real earnings observed in the last three reported periods persist until their expected claiming date. The actual claiming age is used if respondents have already claimed Social Security benefits. For those yet to claim, we assume that respondents claim Social Security benefits at their self-reported expected retirement age. If the expected retirement age was greater than 70 , or if the individual indicated that he never expected to retire, a retirement age of 70 is used unless the individual had already worked beyond that age. If the respondent did not provide an expected retirement age, we assign them a claiming age so that the age distribution of claiming matches the Social Security reported claiming ages (U.S. Social Security Administration 2010, Table 6.B5.1). Combining the actual earnings with the simulated earnings yields a complete earnings profile for each individual in the HRS sample from 1951 to retirement age.

${ }^{9}$ In cases where spouses are of different ages, their AIMEs are indexed to different years (although we adjust them for inflation to bring them to same year dollars - the year when both spouse first are receiving benefits). The overall effect of this different indexing on the denominator of the couple's replacement rate depends on the distribution of wife and husband's individual replacement rates, and age differences in the population. To the extent that the
} 
Earnings after age 60 are not indexed. AIME is the simple monthly average of the indexed earnings in the 35 highest-earnings years. A retiree is entitled to a benefit equal to the PIA at the FRA. A worker may choose to retire as early as age 62 , with reduced benefits. If a worker delays receipt of benefits to an age as late as 70 , the eventual benefits are permanently increased for each year of delay.

Marital status at the age of retirement and marital history are important in determining spousal or survivor benefits. For those who have claimed Social Security, marital status is determined at the time of first benefit receipt. In the HRS data for those not yet retired, the assumption is that last reported marital status does not change before retirement. If divorced with a previous marriage that lasted 10 or more years, we first determine if the ex-spouse is in the sample. If the ex-spouse is not in the sample, we match the respondent to someone else in the survey by gender, education, race, and 5-year birth year band. We then use the earnings histories of the matched spouse to compute the spousal and survivor benefit available from the ex-spouse. For the widows (widowers) whose deceased spouses are missing from the sample, we match the respondents with another widow(er) in the sample, based on gender, race, education, 5-year birth cohort, and retirement age. We then use the earnings histories of that person's deceased spouse to estimate survivor benefits.

The calculation of benefits is done in an analogous way using data from MINT. MINT observes marriage patterns in the periods covered in the SIPP panels when husbands and wives can be precisely identified. For individuals projected to change marital status after the last SIPP observation (or whose former spouses from before the SIPP panel are not observed), the model statistically matches married individuals with a spouse with characteristics of a likely match. The spousal and survivor benefits then are calculated using these observed and imputed spouses.

majority of couples in our dataset have wives who are younger, and wives tend to have higher individual replacement rates than husbands, and to the extent that wages grow faster than inflation, our household replacement rates for couples might be a bit overstated, as compared to a situation when both spouses have earnings wage indexed to the same year. 


\section{Mortality Adjustments}

In the $2010 \mathrm{HRS}$, a portion of WB and EBB respondents are not yet retired, so mortality adjustments are needed because some may die before claiming. ${ }^{10}$ The mortality assumptions are imbedded in MINT; therefore, no additional adjustments or projections are needed (see Smith et al. 2010, page II-11).

\section{Social Security Replacement Rates}

For currently married households, the replacement rate is the ratio of household benefits, which is the sum of the benefits of both husband and wife, to the sum of AIMEs of the couple. It is calculated at the first time that both spouses are receiving their Social Security benefits. In the case of individuals who find themselves widowed or divorced at the time they first start receiving benefits, we create a lifetime shared earnings measure, which equals the individual's earnings in years when he was not married and the average of the couple's earnings in years in which he was married. Thus, the household replacement rate for widowed and divorced persons is the ratio of the benefit that the widow(er)/divorcee receives to the average lifetime shared indexed earnings. At the individual level, the replacement rate is calculated as the ratio of the benefit this individual receives (can be spouse/survivor or retired worker benefit) to his/her own career average indexed earnings. ${ }^{11}$

\section{The Picture by Cohort}

The data from the HRS for the Depression Era (1 and 2), WB, and EBB cohorts suggest several reasons why Social Security replacement rates have changed over time (Table 1). Marriage rates have declined across cohorts, and the labor force participation of women has increased (based on Social Security quarters of coverage). ${ }^{12}$ The share of individuals that are

\footnotetext{
${ }^{10}$ The mortality assumptions imbedded in these calculations start with mortality tables from the SSA, which have data by age and gender. These tables are then adjusted, based on Brown, Liebman and Pollet (2002), to reflect the fact that survival probabilities vary with education and race. We estimate the average mortality rate for each calendar year starting from 2010 through 2045 (the year that the youngest person of the Generation X reaches age 70); then based on these estimated mortality distributions, we assign a death year to individuals with the lowest survival probability at that specific year. For instance, if $5 \%$ of the sample is expected to die in 2011, we assign individuals at the bottom 5 percent of the survival probability distribution a death year of 2011.

${ }^{11}$ For individuals who do not have positive lifetime earnings, the replacement rate is undefined.

${ }^{12}$ Social Security pays retired-worker benefits to individuals who have accumulated 40 or more quarters of earnings in covered employment over their lives. Therefore, the average quarters of work is a crucial factor in benefit eligibility. An individual can earn up to 4 quarters of coverage per year. The amount of earnings for a quarter of
} 
divorced or never married when they first claim has risen from about 29 percent to 44 percent. Quarters of work have increased dramatically for women, by about 20 to 40 percent over time for the married, widowed, and divorced. These changes have increased the share of women eligible for Social Security retired-worker benefits based on their own earnings: only 50 percent of women were eligible for benefits as a retired worker for the Depression Era 1 cohort compared to 73 percent for the EBB. ${ }^{13}$ At the same time, women eligible for only auxiliary benefits declined from 25 percent for the oldest cohort to about 9 percent. Along with the increased female labor market attachment, household AIME has gone up, with the biggest increase for married couples. While the benefits have also increased over time, the changes are relatively modest compared to the changes in AIME, suggesting that replacement rates may fall.

\section{Changes in Replacement Rates over Time}

\section{Current Retirees: Actual Earners in the HRS}

Table 2 presents changes in individual replacement rates from the Depression Era 1 cohort to the EBB, using the HRS data and the methods described above: the median replacement rate for all groups has declined over time, from 47 percent for the Depression Era 1 cohort to 39 percent for the EBB. ${ }^{14}$ The aggregate trend masks more complex patterns by gender and marital status. The decline is more dramatic for women than for men. And the drop in the replacement rate for women is substantially larger for the currently married, divorced, and widowed compared to the never married. These patterns reflect the changing labor force participation of married women. The more that married women work, the more they earn their own benefits, which reduces their eligibility for spousal benefits and lowers their replacement rate.

The change in median household replacement rates largely mirrors that of individual replacement rates (Table 3). ${ }^{15}$ Among married couples, the results are broken down by "single-

coverage in 2012 was $\$ 1,130$. Since most jobs are covered by social security, Social Security quarters of coverage is a good proxy for measuring the labor market attachment.

${ }^{13}$ See also table 5.A14 in the Annual Statistical Supplement to the Social Security Bulletin (U.S. Social Security Administration 2011) for similar comparison of the distribution of women's benefit entitlement over time.

${ }^{14} \mathrm{We}$ use median for replacement rates in order to make the descriptive statistics easily comparable to previous studies and because replacement rates are more prone to outliers - e.g. cases where earnings are very low - such as the cases of widows and divorced women. This is not a concern for other variables in Table 1.

${ }^{15}$ When replacement rates are evaluated at household-level, each married couple household only counts once; and the household observation is assigned to the birth cohort of the husband. 
earner" and "two-earner" households; a single-earner household is one in which only one spouse works long enough to qualify for Social Security worker benefits, and two-earner households are defined as both spouses qualifying for benefits based on own earnings history. ${ }^{16}$ The results show that the decline is particularly large for two-earner households compared to single-earner households. This outcome reflects the fact that working wives add substantially more to the couple's pre-retirement earnings than they do to their Social Security benefits. ${ }^{17}$

Tables 4.1-4.3 shifts the focus from marital status to earnings and show replacement rates of married couples by the husband's earnings. The replacement rate has declined relatively more for households with husbands in the top tercile of the earnings distribution than for households with a husband in the bottom tercile, in terms of changes in proportion from the baseline. This pattern likely reflects the change in the correlation of husbands' and wives' earnings. Schwartz (2010) reports that the earnings of husbands and wives were negatively correlated in the late 1960s and 1970s but as highly educated women went to work, the correlation became positive.

\section{Future Retirees: Projections Using MINT}

Although the growth in women's labor supply has slowed, later cohorts will have a much larger percentage of women who will have spent most of their lives in the labor force. Further, the share of women who are never married or divorced among all women reaching retirement has increased and will continue to increase. These two phenomena suggest that replacement rates for future retirees will keep changing. To investigate to what extent the replacement rate changes by birth cohort, specifically, for future retirees, we use MINT to project replacement rates for Middle Baby Boomers, Late Baby Boomers, and Generation X. The results are presented in Tables 5 and 6 (vs Tables 2 and 3 for the HRS sample).

While the main motivation of using MINT is to project outcomes for future retirees, the rich information in MINT also allows us to estimate replacement rates for earlier cohorts, which provides an external comparison to our HRS estimates. Comparing overlapped cohorts shows that MINT and HRS estimates of replacement rates are largely consistent, although MINT estimates are somewhat higher and the estimated decline for the first four cohorts is slightly

\footnotetext{
16 “Two-earner" households include those where one spouse is dually entitled. Respectively, 'single-earner' households are those in which one of the spouses is eligible only for auxiliary benefits.

${ }^{17}$ It should be mentioned that by definition our measures are censored at the tax maximum and as a result they cannot capture the effects at the very top of the earnings distribution.
} 
smaller (Tables 5 and 6). For instance, while the HRS data show that replacement rates of currently married households declined from 46 percent to 37 percent (about 19.5 percent from baseline) between the Depression Era 1 and EBB cohorts (Table 3), MINT shows a decline from 47 to 42 percent (about 11 percent, Table 6).

A close look at demographics of the MINT sample reveals possible sources of the difference (Table 7 vs. Table 1). Compared to the HRS, the MINT sample is relatively more educated, more likely to be married, and less likely to be divorced or never married. In terms of labor force participation, while the females of the HRS sample work more than those of MINT, the males work less. Consequently, the proportion of females that is eligible for own retired worker benefit is higher for the HRS sample compared to the MINT sample. In addition, across groups, beneficiaries in the HRS have higher AIME values as compared to MINT, which is likely contributing to lower replacement rates on average. While investigating what embedded assumptions of MINT lead to these differences is outside the scope of this study, the differences between MINT and the HRS should be taken into account when assessing projections for future retirees.

The characteristics of future retirees reveal a continuing decline in the share of households that retire as married couples, and an increase in never married and divorced households as a share of households at retirement. Table 7 also shows that the number of quarters covered keeps rising for women of younger cohorts. Consequently, more women will be eligible for own worker benefits at retirement, with the fraction increasing from 68 percent for the EBB to 75 percent for Generation Xers.

Projections from MINT indicate that the replacement rate will continue to decline for future retirees. ${ }^{18}$ At the individual level, the replacement rate will decline from 46 percent for the EBB to 40 percent for Generation X (Table 5), and at the household level, the decline is from 45 percent to 39 percent (Table 6). Further, for both the earlier and later cohorts, the decline in replacement rates occurs across all income groups, but is more pronounced in the highest income tercile (Tables 8.1-8.3). This pattern reflects the influx of highly educated women into the workforce among the two-earner couples.

\footnotetext{
${ }^{18}$ While the declining replacement rates indicate that benefits as a percent of pre-retirement earnings are expected to drop, the benefits in real terms are expected to keep rising for all household groups (see table 7).
} 
Surprisingly, MINT projects that replacement rates will decline more for single-earner households than for two-earner households: moving from EBB to Generation X, replacement rates are projected to drop from 54 percent to 38 percent for single-earner households. This sharp decline, which is concentrated in the last two cohorts, is surprising and quite different from the experience of older cohorts. It is primarily driven by projected changes in the nature of single-earner households. The percent of single-earner households in which spouses receive benefits solely based on the husband's earnings record is projected to drop sharply for the Later Boomers and Generation Xers, from 72 percent for EBB to 64 percent for the GX cohort (not shown). At the same time, the share of households in which spouses receive benefits based on the wife's work history will increase. The latter type of households tends to have lower replacement rates, because a husband who is not eligible for Social Security benefits based on his own working history usually has worked more and earned more than a non-eligible wife. As a result, a non-eligible husband ends up contributing more to the denominator of the replacement rate.

In summary, the analysis using the HRS and the MINT both show declining individual and household replacement rates. Moreover, the simulations for future retirees indicate that the increasing labor force participation of women will continue to put downward pressure on Social Security replacement rates for future retirees.

\section{Explaining Differences over Time: Oaxaca-Blinder Decomposition \\ Conceptual Framework}

This section measures how much of the decline in replacement rates can be explained by the changing lives of women - labor force participation and marriage patterns - as opposed to the other major explanation - reductions due to the extension of the FRA and early claiming.

Claiming behavior could be particularly important because, as a result of the 1983 Amendments, Social Security's FRA is rising from 65 to 67 . The actuarial reduction for early claiming means that if younger cohorts do not postpone claiming to keep pace with the scheduled changes in the FRA, they will face a lower replacement rates than older cohorts. Figure 4 shows the magnitude of the decline by comparing the ratio of benefits claimed at the 
EEA versus the FRA by cohort. ${ }^{19}$ MINT also projects that the actual claiming age will increase from 63.5 for those born in the early 1930s to 64.1 for Generation Xers (Table 7). ${ }^{20}$

The method used to examine how much of the gaps in replacement rates between birth cohorts can be explained by differences in observable characteristics, including labor force experience, marriage patterns, and claiming behavior is based on the work of Oaxaca (1973) and Blinder (1973), a decomposition method widely used in social science research. Essentially, this decomposition involves calculating what one cohort's outcomes would have looked like if it had the characteristics of another cohort. The approach involves estimating the following linear regression model to predict household replacement rates for individuals at retirement:

$$
R_{i}=X_{i} \beta_{i}+\varepsilon_{i}
$$

where $R_{i}$ denotes the household replacement rate for individual i, $X_{i}$ denotes a set of observed characteristics and a constant, $\beta_{i}$ contains the slope parameters and the intercept, and $\varepsilon_{i}$ is a random error term. To explore the difference between two cohorts, we estimate two parallel models for each cohort separately:

$$
\begin{aligned}
& R_{C 1}=X_{C 1} \beta_{C 1}+\varepsilon_{C 1} \\
& R_{C 2}=X_{C 2} \beta_{C 2}+\varepsilon_{C 2}
\end{aligned}
$$

where $C 1$ denotes cohort1 and $C 2$ denotes cohort 2, and the error terms $\varepsilon_{C 1}$ and $\varepsilon_{C 2}$ are mean zero. The difference between the mean outcomes of these two cohorts is:

$$
E\left(R_{C 1}\right)-E\left(R_{C 2}\right)=\overline{X_{C 1}} \beta_{C 1}-\overline{X_{C 2}} \beta_{C 2}
$$

\footnotetext{
${ }^{19}$ Similarly, because delayed retirement credits accrue only till age 70, for later cohorts the maximum benefit as a percent of the full retirement benefit will be lower as compared with earlier cohorts.

${ }^{20}$ Based on MINT's projection, the trend in claiming ages has been flat since the EBB. Part of the reason is that MINT's OASI-claiming model does not explicitly build in the rising FRA or cohort effects as covariates in estimation and then projection. See page IV-10, table 4-4 in Smith et al. (2010) for detailed description of model specification and list of independent variables. However, MINT 6 partially accounts for the higher FRA, by estimating and simulating two separate models depending on whether the individual is subject to the Retirement Earnings Test (RET), which in 2000 was suspended after reaching FRA. As the FRA increases, working individuals in future cohorts will be subjected to the RET for longer periods in their 60s, thus they are projected to be more likely to delay claiming. The resulting distribution of claiming ages, of course, will also depend on the extent to which individuals belonging to various socio-demographic groups are likely to be working enough, so as to be subjected to the RET. As the authors indicate in the text: "These estimates are based on a sample of individuals for whom the FRA for Social Security ranged from 65 to 66. As the FRA continues to increase to 67, these algorithms automatically slow claiming for higher earners at younger ages (those with earnings above the retirement earnings test exempt amount), but they do not generally slow claiming for lower earners (all else equal)." When interpreting the decomposition results, one should be cautious of the possibility that the current version of MINT might be somewhat underestimating the claiming age of younger cohorts,
} 
By adding and subtracting both $\overline{X_{C 1}} \beta_{p}$ and $\overline{X_{C 2}} \beta_{p}$ to the right-hand side, the equation can be rewritten as:

$$
E\left(R_{C 1}\right)-E\left(R_{C 2}\right)=\left(\overline{X_{C 1}}-\overline{X_{C 2}}\right) \beta_{p}+\left(\beta_{C 1}-\beta_{p}\right) \overline{X_{C 1}}+\left(\beta_{p}-\beta_{c 2}\right) \overline{X_{C 2}}
$$

where $\beta_{p}$ is the coefficient from a pooled regression in either cohort (Neumark 1988). ${ }^{21}$ This equation decomposes the difference between outcomes in populations $C 1$ and $C 2$ into the portion that can be explained by differences in the mean of the variables $X$ in the two groups (the first part commonly called the "explained" portion) and the portion owing to differences in the coefficients between the two groups for the same values of $X$ (commonly referred to as the "unexplained" portion; including differences in the intercept). ${ }^{22}$

In the main analysis, the $X$ vector includes three major components that could contribute to the difference across cohorts: marital status $(M)$; labor supply $(L)$; and claiming behaviors $($ Bratio $)$. The vector for marital status $(M)$ includes dummies for married, widowed, and divorced; the vector for labor supply $(L)$ includes total number of covered quarters, a dummy of whether worked over 40 quarters, and a measure of average lifetime earnings. ${ }^{23}$ Bratio is the outcome of claiming behavior, given the extension of the FRA across cohorts; it is constructed as the ratio of actual to full benefits, as a result of the individuals claiming early and receiving an actuarially reduced benefit, or claiming late and receiving delayed retirement credits. ${ }^{24}$ In addition, the model also controls for changes in education, race, and gender over time; these factors are grouped in $D$ vector. $\varepsilon$ is a random error term with mean zero.

\footnotetext{
${ }^{21}$ As discussed in the literature, the Blinder-Oaxaca decomposition incurs the index number problem, implying that decomposition is unstable depending on the choice of the reference group. In order to overcome the index number problem, Neumark (1988) proposes a general decomposition which is based on a pooled regression and involves using the weighted average of two groups, and this pooled decomposition Neumark (1988) proposed has been adopted as the primary approach to measure explained and unexplained gaps in a number of empirical studies (Elder, Goddeeris, Haider 2010). While there are other modifications of the Oaxaca-Blinder method, we adopt the Neumark (1998) version in this paper.

${ }^{22}$ It is important recognize that the "unexplained" portion also captures all potential effects of differences in unobserved variables.

${ }^{23}$ Average lifetime earnings are constructed by averaging the individual's ratio of nominal earnings to the AWI over his working life. Since the initial Social Security benefits are wage-indexed, this measure directly relates lifetime earnings to the resulting replacement rate.

${ }^{24}$ Over time, the Bratio has declined, from 0.9 for the Depression Era cohort to 0.83 for the GX cohort. The potential endogeneity of the Bratio variable will be discussed in next section.
} 


\section{Empirical Results}

The results of estimating equation (5) are summarized in Table 9, which decomposes the differences in mean replacement rates between cohorts to its contributing factors. ${ }^{25,26}$ Overall, the difference in average replacement rates between the oldest cohort (the Depression Era 1 cohort) and the youngest (the Generation X cohort) is about 13 percentage points. ${ }^{27,28}$ Changes in labor supply, including labor force attachment and lifetime earnings, together explain about 32 percent of the difference in replacement rates between the oldest and youngest cohorts. ${ }^{29}$

Moreover, when comparing the oldest cohort to cohorts that are closer to it in terms of birth year, the labor force supply and earnings account for an even bigger percent of the change -- ranging from 31.7 to 74.6 percent. For instance, the labor force supply and earnings explain over 67 percent of the change when comparing Depression Era 1 cohort to Depression Era 2 cohort.

Changes in marital status over time also impact the replacement rate, but in a direction that is in some cases opposite to the effect of labor supply, particularly when comparing cohorts further apart. $^{30}$ Since married couples have, on average, lower replacement rates compared to other groups, the decline in the share of married households leads to an increase in the replacement rate. ${ }^{31}$ In terms of magnitude, these effects are small though statistically significant. Changes in marital patterns account for less than 3 percent of the difference in mean replacement rates between the oldest and youngest cohort in our sample (Table 9).

\footnotetext{
${ }^{25}$ For the purpose of consistency, we report the decomposition results using MINT. The results are largely consistent for overlapped cohorts using the HRS data. These results are available upon request.

${ }^{26}$ The detailed regressions results by cohort, as well as the mean values of the covariates and the results of the pooled regressions are available from authors upon request.

${ }^{27}$ The decline in replacement rate between the oldest and youngest cohort is slightly bigger here than in table 5 simply due to the fact that table 5 present medians, while the decomposition model compares means because by construction the Oaxaca-Blinder methodology decomposes the mean differences.

${ }^{28}$ The Blinder - Oaxaca model decomposes the mean differences in household replacement rates. In the case of married couples, each member is treated as a separate observation and husband and wife can appear in different birth cohorts.

${ }^{29}$ While we separately control for total number of covered quarters, and eligibility status in the form of an indicator of whether worked over 40 quarters, and a measure of average lifetime earnings in the regression model for simplicity of exposition. The table reports the total effect for these three components of labor supply. The separate effect of each component is available from authors upon request.

${ }^{30}$ While we separately control for dummies for married, widowed, and divorced, the table reports the total effect for these three components of marital patterns. The separate effect of each component is available from authors upon request.

${ }^{31}$ One should note that our measures capture just the percent of average lifetime earnings that Social Security benefits replace in retirement. An alternative way to compare wellbeing across households would be to use equivalence scales to account for the economies of scale in consumption that married couples enjoy. This, however, is out of the scope of this paper.
} 
Claiming behavior given the extension of the FRA over time, however, is also an important factor that accounts for over a third of the change in replacement rates between the oldest and the youngest cohorts. The reason for the effect of claiming behavior is that even though the younger generations are projected to retire later, this delay is not sufficient to keep pace with the increase in the FRA. As a result, MINT expects a larger portion of future retirees to face an actuarial reduction in their benefits.

Additionally, changes in demographic factors, such as race, gender, and education also explain about 5 percent of the total decline in replacement rates over time. Finally, although differences in three major factors, labor force activities, marital status, and claiming behavior given the extension of the FRA over time can account for much of the decline in replacement rates over time, over 30 percent of the change between the oldest and the youngest cohort remains unexplained. The unexplained component is bigger when comparing cohorts that are further apart, suggesting that these unexplained differences could in part be driven by the underlying assumptions used for the projections.

The Blinder-Oaxaca analysis is repeated for women only (Table 10). The pattern is largely consistent with that for all households, although changes in labor supply and earnings explain a larger fraction of the change in mean replacement rates across cohorts. About half (50.6 percent) of the difference is explained by the changes in labor supply and earnings when comparing replacement rates between the oldest and the youngest cohorts. Further, the "unexplained" part is much smaller (15.6 percent), which is consistent with the fact that the changes in replacement rates over time is primarily driven by the changing role of women.

Finally, the Blinder-Oaxaca decomposition analysis is applied to different marital status groups (Table 11). The results are largely consistent, except that changing claiming behaviors given the extension of the FRA play a much more important role for the divorced and never married groups, accounting for nearly 50 percent of the change in replacement rates between the oldest and the youngest cohorts. For the married, the model also controls for spouses' characteristics. By doing so, this exercise provides further evidence on how marriage, specifically assortative mating, impacts replacement rates. ${ }^{32}$ The results show that spouse's labor

\footnotetext{
${ }^{32}$ The literature has documented substantial changes in assortative mating patterns over time. In addition to what we have mentioned in a previous section i.e., that the correlation between spouses' earnings has become positive from negative over time, couples are becoming more similar in other dimensions and rather than marrying up, more women are marrying down in terms of education (Rose 2001).
} 
supply and earnings, and claiming behaviors play a nearly equally important role as the individual's own labor supply and earnings and claiming decisions in explaining changes in household replacement rates over time.

\section{Alternative Specifications}

The results from our main model reveal the importance of individuals' claiming behavior on replacement rates. By design the variable that captures the effect of claiming behavior, Bratio, reflects the actuarial reduction or delayed retirement credit applied to an individual's full benefit and thus is a function of both the age of claiming and the individual's FRA which has increased over time for individuals in our sample. While Bratio does not separately identify the impact of claiming from that of the law change, its inclusion is important to the empirical specification because its omission would have confounded the estimates of the impacts of labor supply and marriage rates.

Alternatively, to isolate the impacts of our main variables of interest from the impacts of claiming and law changes, we compare trends in household replacement rates at actual claiming ages with what they would have been had all units claimed at the FRA (Table 12). ${ }^{33}$ As expected, Table 12 reveals higher median replacement rates at FRA, as compared with replacement rates at actual claiming age. Further, we find an overall smaller decline in replacement rates over time for all groups.

We estimate decomposition models at the FRA to mitigate the effects of potential behavioral responses to the scheduled FRA increase and to provide a robustness check to the earlier estimation results. By defining the full-retirement-age replacement rates as the outcome variable, we remove the variable Bratio from the right hand side of the model and avoid potentially confounding effects of the previous specification.

The estimates are summarized in Tables 13, 14 and 15 for the full sample of households, only women, and by marital status, respectively. In the absence of the effect of claiming behavior, difference in labor supply, including labor force attachment and earnings can explain

\footnotetext{
${ }^{33}$ Doing a full counterfactual exercise in which individuals and households are forced to claim benefits at the FRA is quite complex and involves many assumption as to how it would affect labor supply, earnings and potentially effects on the AWI and other aggregate macro variables. The exercise is beyond the scope of this paper. Instead, for illustrative purposes we calculate benefits at the FRA by simply adjusting the benefit levels to offset the effects of the actuarial reduction for one's early claiming or for delayed retirement credits.
} 
over 70 percent of the gap in replacement rates between the Depression Era 1 cohort and the following generations up to the Middle Boomers, and about half of the difference between the oldest and youngest cohorts (Table 13). Marital patterns have a statistically significant but economically small effect. ${ }^{34}$ Changing demographics also only account for a small percent of the difference. Again, a big portion (half) of the difference with the last two cohorts remains unexplained by differences in mean characteristics and is instead attributed to the changes in the returns to the factors ( that is, due to changes in the coefficient estimates, rather than difference in mean characteristics) or unobservables.

In the case of the estimations for women, higher labor force participation and earnings account for almost all of the difference in replacement rates for some of the earlier cohorts and about 74 percent of the difference in replacement rates for the earliest and latest cohorts in the sample. $^{35}$

To summarize, decomposing the source of the change in replacement rates over time shows that changes in labor supply and earnings, and the extension of the FRA and changes in claiming behavior each explain about one third of the difference in replacement rates between the oldest and youngest cohorts. When comparing replacement rates at the FRA, labor supply and earnings solely explain about half of the difference between the oldest and youngest cohorts, and three fourths or more of the difference for cohorts up to the Middle Baby Boomers. Demographics, including marital status, which has changed dramatically over time, have only a small effect. A significant share of the change between oldest and youngest remains unexplained, that is, not attributable to differences in mean characteristics between the cohorts.

\section{Conclusion}

This paper examines the extent to which the changing role of women impacts Social Security replacement rates. It first documents substantial changes in women's labor force

\footnotetext{
${ }^{34}$ Marital status appears with overall insignificant effect for most cohorts in the specifications including only women. The reason is that significant effects on married, widowed and divorced (never married is the omitted category) offset each other in magnitude. Detailed decomposition results including the marital groups are available from the authors upon request.

${ }^{35}$ Further, we also conduct the decomposition analysis using the latest cohort, the Generation X, as the baseline. Overall the results are consistent with the previous finding of strong effects of labor supply and earnings, and much smaller effect of changing marriage rates. With this approach we also find that the model explains consecutive cohorts better (the unexplained portion is smaller) and in fact shows almost no difference in outcomes between the youngest two cohorts (Late Baby Boomers and Generation X). The results are available from the authors upon request.
} 
participation and marital status over time. Then the study estimates changes in Social Security replacement rates when first claiming across a broad range of cohorts: for those born between 1931 and 1975. It compares estimated replacement rates of current retirees using different datasets, and it further projects replacement rates for future retirees. The results show that there has been a marked decrease in the proportion of pre-retirement income that Social Security replaces. Moreover, this trend will continue for years to come. This outcome is positive for Social Security's finances. Over one third of the decline in replacement rates across cohorts can be explained by the increased labor supply and earnings of women. Surprisingly, trends in marriage patterns account for only a small fraction of the change in replacement rates over time. Much of the remaining explanation rests with the increased FRA and changing claiming behaviors. As people are living longer but many are still retiring in their early 60 s, the declining role for Social Security implies that retirees will have to rely increasingly on other sources of retirement income. 


\section{References}

Anderson, Patricia M., Alan L. Gustman, and Thomas L. Steinmeier. 1999. "Trends in Male Labor Force Participation and Retirement: Some Evidence on the Role of Pensions and Social Security in the 1970's and 1980's." Journal of Labor Economics 17(4): 757-783.

Blinder, Alan S. 1973. "Wage Discrimination: Reduced Form and Structural Estimates." Journal of Human Resources 8(4): 436-455.

Brown, Jeffrey R., Jeffrey B. Liebman, and Joshua Pollet. 2002. "Estimating Life Tables that Reflect Socioeconomic Differences in Mortality." In The Distributional Aspects of Social Security and Social Security Reform, edited by Martin Feldstein and Jeffrey B. Liebman, 447-457. Chicago IL: University of Chicago Press.

Burkhauser, Richard V. and Karen C. Holden, eds. 1982. A Challenge to Social Security: The Changing Roles of Women and Men in American Society. New York, NY: Academic Press.

Butrica, A. Barbara and Howard M. Iams. 2000. "Divorced Women at Retirement: Projections of Economic Well-Being in the Near Future.” Social Security Bulletin 63(3): 3-12.

Butrica A. Barbara, Howard M. Iams, and Steven H. Sandell. 1999. "Using Data for Couples to Project the Distributional Effects of Changes in Social Security Policy." Social Security Bulletin 62(3): 20-27.

Butrica, A. Barbara, Howard M. Iams, and Karen E. Smith. 2007. "Understanding Baby Boomer Retirement Prospects." In Redefining Retirement: How Will Boomers Fare? edited by Brigitte Madrian, Olivia S. Mitchell, and Beth J. Soldo, 70-94. New York, NY: Oxford University Press.

Butrica, A. Barbara and Karen E. Smith. 2012a. "The Impact of Changes in Couples' Earnings on Married Women’s Social Security Benefits.” Social Security Bulletin 72(1): 1-10.

—. 2012b. "The Retirement Prospects of Divorced Women." Social Security Bulletin 72(1): 11-22.

Butrica, A. Barbara, Karen E. Smith, and Howard M. Iams. 2012. "This is Not Your Parents' Retirement: Comparing Retirement Income Across Generations." Social Security Bulletin 72(1): 37-58.

Congressional Budget Office. 1986. Earnings Sharing Options for the Social Security System. Washington, DC.

Elder, Todd E., John H. Goddeeris, and Steven J. Haider. 2010. "Unexplained Gaps and OaxacaBlinder Decompositions.” Labour Economics, Vol. 17, No. 1. (2010), pp. 284-290. 
Favreault, Melissa M., Frank J. Sammartino, and C. Eugene Steuerle, eds. 2002. Social Security and the Family: Addressing Unmet Needs in an Underfunded System. Washington, DC: Urban Institute Press.

Ferber, Marianne A. 1993. "Women's Employment and the Social Security System.” Social Security Bulletin 56(3): 33-55.

Gustman, Alan L. and Thomas L. Steinmeier. 2001. "How Effective is Redistribution under the Social Security Benefit Formula?” Journal of Public Economics 82(1): 1-28.

Haider, Steven and Gary Solon. 2000. "Nonrandom Selection in the HRS Social Earnings Sample.” Working paper 00-01. Santa Monica, CA: RAND Corporation.

Harrington Meyer, Madonna. 1996. "Making Claims as Workers or Wives: The Distribution of Social Security Benefits.” American Sociological Review 61(3): 449-465.

Iams, Howard M., John W. R. Phillips, Kristen Robinson, Lionel P. Deang, and Irena Dushi. 2009. "Cohort Changes in the Retirement Resources of Older Women." Social Security Bulletin 68(4): 1-13.

Kapteyn, Arie, Pierre-Carl Michaud, James Smith, and Arthur van Soest. 2006. "Effects of Attrition and Non-Response in the Health and Retirement Study." Working Paper WR407. Santa Monica, CA: RAND Corporation.

Kreider, Rose M. and Renee Ellis. 2011. "Number, Timing, and Duration of Marriages and Divorces: 2009." Current Population Reports P70-125. Washington, DC: U.S. Census Bureau.

Munnell, Alicia H., Geoffrey Sanzenbacher, and Mauricio Soto. 2007. "Working Wives Reduce Social Security Replacement Rates." Issue in Brief 7-15. Chestnut Hill, MA: Center for Retirement Research at Boston College.

Neumark, David. 1988. “Employers' Discriminatory Behavior and the Estimation of Wage Discrimination." Journal of Human Resources 23(3): 279-295.

Oaxaca, Ronald. 1973. "Male-Female Wage Differentials in Urban Labor Markets.” International Economic Review 14(3): 693-709.

Purcell, Patrick J. 2012. "Income Replacement Ratios in the Health and Retirement Study." Social Security Bulletin 72(3): 37-58.

Rose, Elaina. 2001. "Marriage and Assortative Mating: How Have the Patterns Changed?" Working Paper 22. Seattle, WA: Center for Statistics and the Social Sciences, University of Washington. 
Ross, Jane L. and Melinda M. Upp. 1993. "Treatment of Women in the U.S. Social Security System, 1970-88.” Social Security Bulletin 56(3): 56-67.

Schwartz, Christine. 2010. 'Earnings Inequality and the Changing Association between Spouses' Earnings.” American Journal of Sociology 115(5): 1524-1557.

Smith, Karen E., Melissa Favreault, Barbara Butrica, and Philip Issa. 2010. "Modeling Income in the Near Term 6." Washington, DC: The Urban Institute.

Smith, Karen E., Melissa Favreault, Caroline Ratcliffe, Barbara Butrica, Eric Toder, Jon M. Bakija. 2007. "Modeling Income in the Near Term 5." Washington, DC: The Urban Institute.

U.S. Bureau of Labor Statistics. 2008. "Highlight of Women's Earnings in 2007.” Report 1008. Washington, DC: U.S. Department of Labor.

U.S. Department of Health, Education, and Welfare. 1979. Social Security and the Changing Roles of Men and Women. Washington, DC.

U.S. Department of Health and Human Services. 1985. Report on Earnings Sharing Implementation Study. Washington, DC: U.S. Government Printing Office.

U.S. Department of Labor. 2010. “Quick Stats on Women Workers, 2010.” Washington, DC. Available at: http://www.dol.gov/wb/factsheets/QS-womenwork2010.htm.

U.S. Social Security Administration. 2012a. The 2012 Annual Report of the Board of Trustees of the Federal Old-Age and Survivors Insurance and Federal Disability Insurance Trust Funds. Washington, DC: U.S. Government Printing Office.

- 2012b. Income of the Population 55 or Older, 2010. Washington, DC: SSA. http://www.socialsecurity.gov/policy/docs/statcomps/income_pop55/2010/index.html. 
Figure 1. Labor Force Participation Rates of Women Aged 25-34, by Birth Cohort and Marital Status

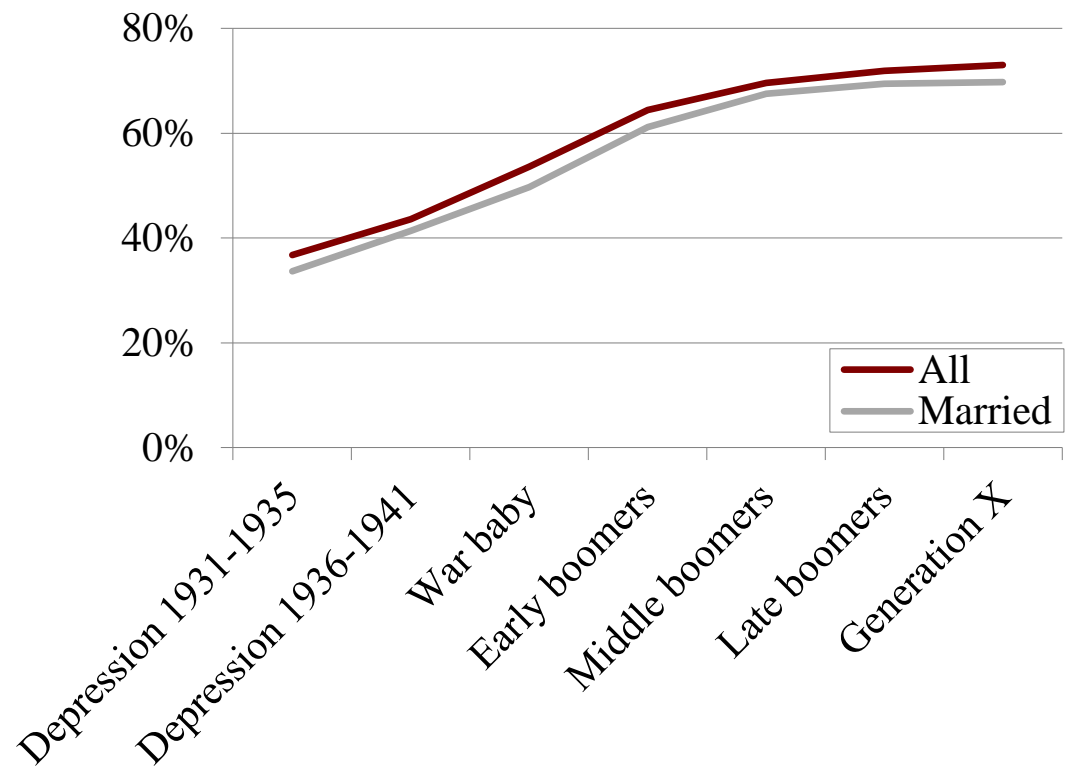

Note: "In the labor force" is defined as having positive earnings during the year.

Source: Authors' calculations based on MINT. 
Figure 2. Median Ratio of Wife's to Husband's Average Indexed Monthly Earnings, by Birth Cohort

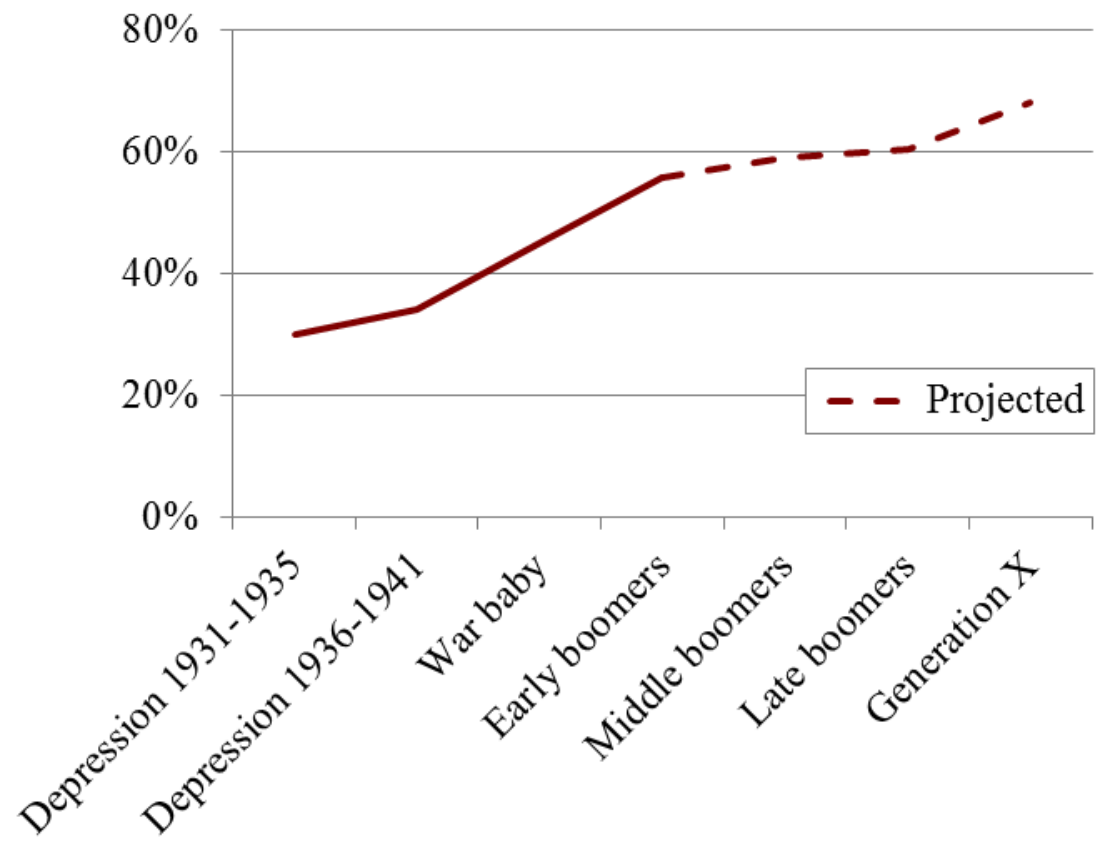

Source: Authors' calculations based on MINT. 
Figure 3. Percent of Women Married, by Age Group by Birth Cohort

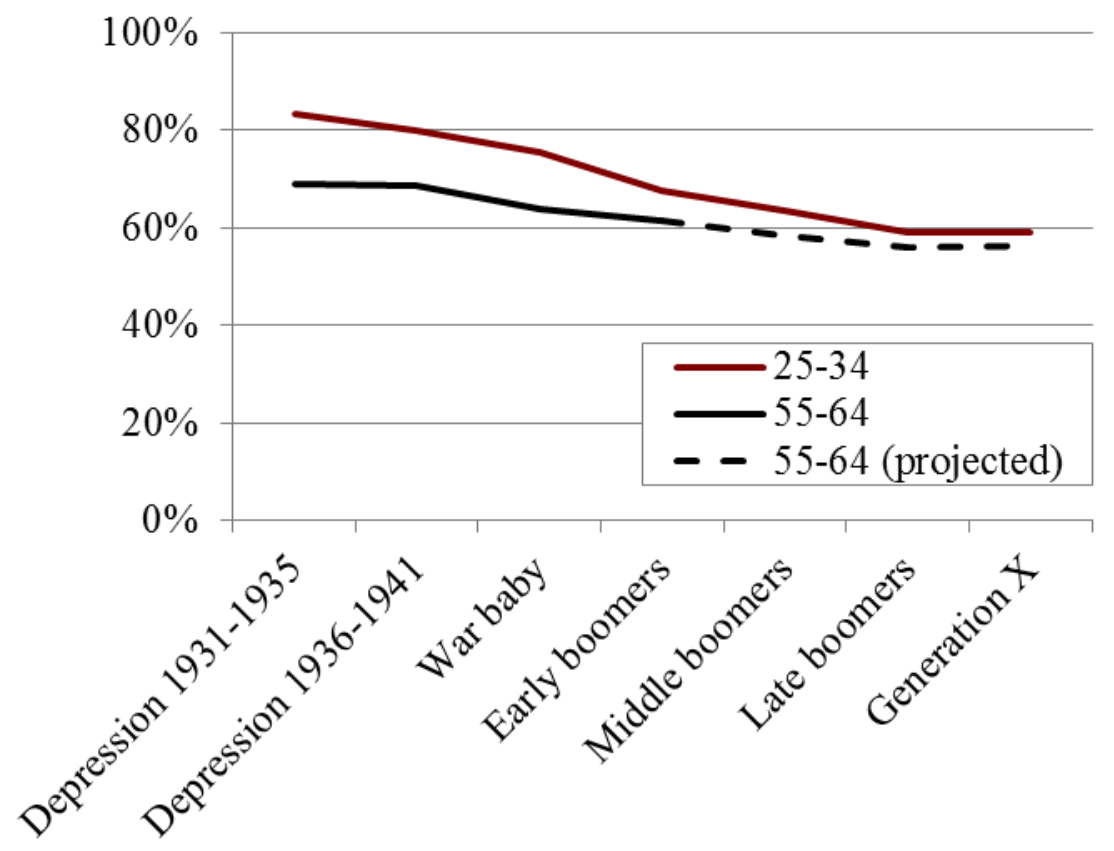

Source: Authors' calculations based on MINT. 
Figure 4. Full Retirement Age and Early Eligibility Benefit as a Percent of Full Retirement Benefit, by Birth Cohort

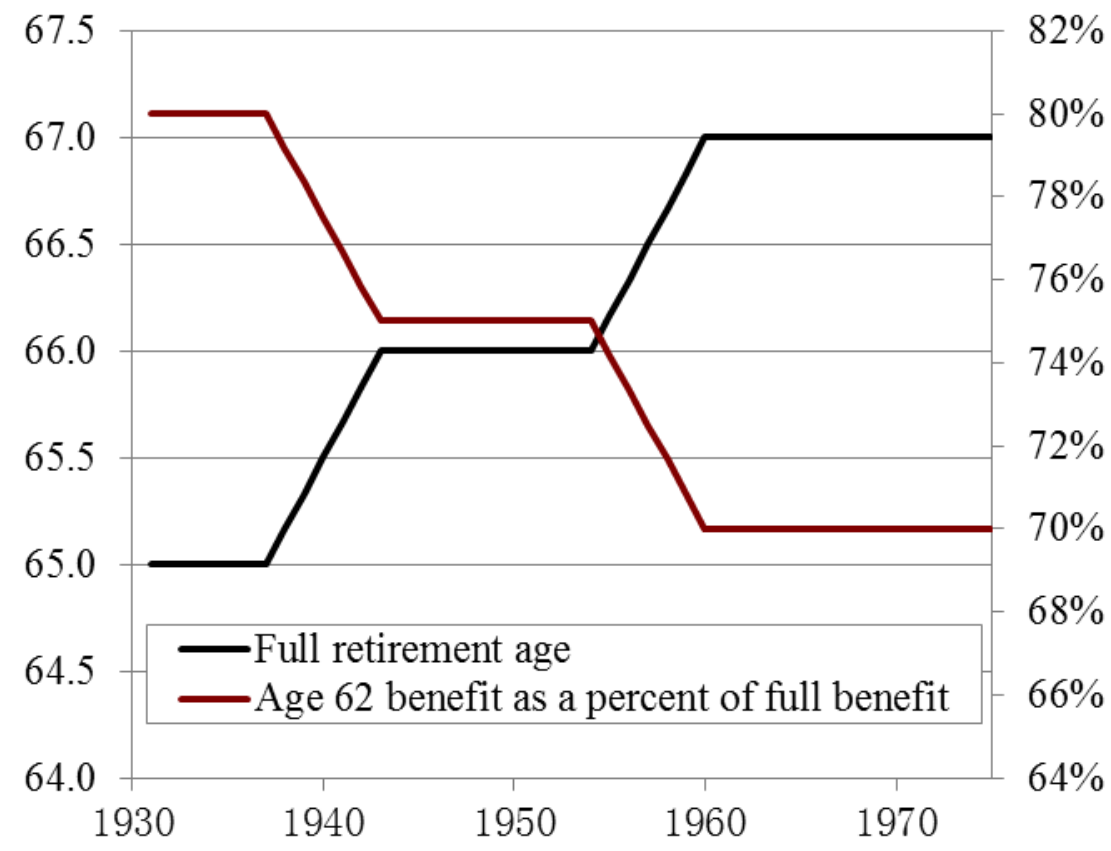

Source: Authors' calculations using U.S. Social Security benefit rules. 
Table 1. Characteristics of Individuals When First Claimed Social Security Benefits, by Birth Cohort

\begin{tabular}{|c|c|c|c|c|}
\hline Characteristics & $\begin{array}{l}\text { Depression } \\
1931-1935 \\
\end{array}$ & $\begin{array}{l}\text { Depression } \\
1936-1941 \\
\end{array}$ & War Baby & Early Boomers \\
\hline \multicolumn{5}{|l|}{ Gender } \\
\hline Men & $46.26 \%$ & $47.62 \%$ & $47.17 \%$ & $46.91 \%$ \\
\hline Women & 53.74 & 52.38 & 52.83 & 53.09 \\
\hline \multicolumn{5}{|l|}{ Marital status } \\
\hline Married & 54.66 & 53.54 & 52.69 & 49.69 \\
\hline Divorced & 22.74 & 29.02 & 31.63 & 35.72 \\
\hline Never married & 5.92 & 5.99 & 6.49 & 8.3 \\
\hline Widowed & 16.68 & 11.45 & 9.18 & 6.29 \\
\hline \multicolumn{5}{|l|}{ Education } \\
\hline Less than HS & 22.02 & 17.27 & 9.87 & 8.83 \\
\hline High School & 57.9 & 58.91 & 60.67 & 56.72 \\
\hline College + & 20.08 & 23.82 & 29.46 & 34.45 \\
\hline \multicolumn{5}{|c|}{ Numbers of quarters covered by gender and marital status } \\
\hline \multicolumn{5}{|c|}{ Women } \\
\hline Married & 89 & 103 & 113 & 124 \\
\hline Divorced & 109 & 114 & 124 & 133 \\
\hline Never married & 145 & 145 & 143 & 153 \\
\hline Widowed & 98 & 95 & 113 & 117 \\
\hline \multicolumn{5}{|l|}{ Men } \\
\hline Married & 147 & 156 & 154 & 154 \\
\hline Divorced & 135 & 144 & 152 & 152 \\
\hline Never married & 122 & 139 & 146 & 147 \\
\hline Widowed & 142 & 151 & 141 & 148 \\
\hline \multicolumn{5}{|c|}{ Benefit type (all women) (\%) } \\
\hline Retired worker & 50.26 & 56.93 & 64.09 & 72.5 \\
\hline Dually entitled & 25.08 & 26.48 & 23.8 & 18.91 \\
\hline Auxiliary only & 24.65 & 16.59 & 12.11 & 8.59 \\
\hline \multicolumn{5}{|c|}{ Average AIME (household level) 2012 dollars (\$) } \\
\hline Married & 55,679 & 70,879 & 81,200 & 89,750 \\
\hline Divorced & 24,786 & 30,951 & 36,551 & 39,769 \\
\hline Never married & 25,258 & 37,799 & 38,924 & 43,330 \\
\hline Widowed & 20,774 & 21,630 & 28,142 & 29,229 \\
\hline \multicolumn{5}{|c|}{ Average benefit (household level) 2012 dollars (\$) } \\
\hline Married & 24,783 & 29,071 & 29,736 & 32,271 \\
\hline Divorced & 11,428 & 13,338 & 14,091 & 14,906 \\
\hline Never married & 10,966 & 14,560 & 14,201 & 15,671 \\
\hline Widowed & 11,805 & 13,528 & 15,063 & 16,626 \\
\hline \multicolumn{5}{|c|}{ Number of observations } \\
\hline & 3397 & 4345 & 2014 & 2544 \\
\hline
\end{tabular}

Source: Authors' calculations based on the HRS. 
Table 2. Estimated Replacement Rates, Individual Level (Median), by Birth Cohort

\begin{tabular}{|c|c|c|c|c|}
\hline & $\begin{array}{l}\text { Depression } \\
1931-1935 \\
\end{array}$ & $\begin{array}{l}\text { Depression } \\
1936-1941 \\
\end{array}$ & War Baby & Early Boomers \\
\hline All individuals & $47 \%$ & $44 \%$ & $39 \%$ & $39 \%$ \\
\hline Men & 38 & 37 & 34 & 35 \\
\hline Women & 65 & 56 & 49 & 45 \\
\hline \multicolumn{5}{|l|}{ Never married } \\
\hline Men & 50 & 45 & 39 & 41 \\
\hline Women & 43 & 41 & 38 & 42 \\
\hline \multicolumn{5}{|c|}{ Currently married } \\
\hline Men & 38 & 37 & 33 & 34 \\
\hline Women & 70 & 56 & 49 & 45 \\
\hline \multicolumn{5}{|l|}{ Widowed } \\
\hline Men & 41 & 37 & 37 & 34 \\
\hline Women & 72 & 82 & 77 & 62 \\
\hline \multicolumn{5}{|l|}{ Divorced } \\
\hline Men & 40 & 39 & 37 & 36 \\
\hline Women & 57 & 52 & 44 & 42 \\
\hline
\end{tabular}

Note: Replacement rate is defined as the unit's Social Security benefit over AIME.

Source: Author's calculations based on the HRS. 
Table 3. Estimated Replacement Rates, Household Level (Median), by Birth Cohort

\begin{tabular}{lcccc}
\hline & $\begin{array}{c}\text { Depression } \\
1931-1935\end{array}$ & $\begin{array}{c}\text { Depression } \\
1936-1941\end{array}$ & War Baby & Early Boomers \\
\hline All households & $47 \%$ & $44 \%$ & $39 \%$ & $39 \%$ \\
Never married & 49 & 44 & 38 & 42 \\
Currently married & & & & \\
$\quad$ Single-earner households & 54 & 53 & 49 & 52 \\
$\quad$ Two-earner households & 43 & 41 & 37 & 36 \\
$\quad$ Combined married households & 46 & 42 & 38 & 37 \\
Widowed & 64 & 68 & 61 & 61 \\
Divorced & 48 & 46 & 40 & 39 \\
\hline
\end{tabular}

Note: Replacement rate is defined as the unit's Social Security benefit over AIME.

Source: Authors' calculations based on the HRS. 
Table 4.1. Estimated Replacement Rates for the Married (Median, Single-Earner Households), by Birth Cohort

\begin{tabular}{ccccc}
\hline & $\begin{array}{c}\text { Depression } \\
1931-1935\end{array}$ & $\begin{array}{c}\text { Depression } \\
1936-1941\end{array}$ & War Baby & Early Boomers \\
\hline $\begin{array}{c}\text { Husband's Earnings } \\
\text { Low }\end{array}$ & $67 \%$ & $71 \%$ & $78 \%$ & $76 \%$ \\
Median & 51 & 52 & 48 & 51 \\
High & 45 & 46 & 39 & 39 \\
\hline
\end{tabular}

Table 4.2. Estimated Replacement Rates for the Married (Median, Two-Earner Households), by Birth Cohort

\begin{tabular}{ccccc}
\hline & $\begin{array}{c}\text { Depression } \\
1931-1935\end{array}$ & $\begin{array}{c}\text { Depression } \\
1936-1941\end{array}$ & War Baby & Early Boomers \\
\hline Husband's Earnings & & & & \\
Low & $52 \%$ & $49 \%$ & $44 \%$ & $45 \%$ \\
Median & 42 & 40 & 36 & 36 \\
High & 37 & 35 & 31 & 30 \\
\hline
\end{tabular}

Table 4.3. Estimated Replacement Rates for the Married (Median, Combined), by Birth Cohort

\begin{tabular}{lcccc}
\hline & $\begin{array}{c}\text { Depression } \\
1931-1935\end{array}$ & $\begin{array}{c}\text { Depression } \\
1936-1941\end{array}$ & War Baby & Early Boomers \\
\hline $\begin{array}{c}\text { Husband's Earnings } \\
\text { Low }\end{array}$ & $57 \%$ & $53 \%$ & $47 \%$ & $48 \%$ \\
Median & 45 & 42 & 38 & 37 \\
High & 38 & 35 & 31 & 30 \\
\hline
\end{tabular}

Note: Replacement rate is defined as the unit's Social Security benefit over AIME.

Source: Authors' calculations based on the HRS. 
Table 5. Estimated Replacement Rates, Individual Level (Median), MINT by Birth Cohort

\begin{tabular}{lccccccc}
\hline & $\begin{array}{c}\text { Depression } \\
\text { 1931-1935 }\end{array}$ & $\begin{array}{c}\text { Depression } \\
\text { 1936-1941 }\end{array}$ & War Baby & $\begin{array}{c}\text { Early } \\
\text { Boomers }\end{array}$ & $\begin{array}{c}\text { Middle } \\
\text { Boomers }\end{array}$ & $\begin{array}{c}\text { Late } \\
\text { Boomers }\end{array}$ & $\begin{array}{c}\text { Generation } \\
\text { Xers }\end{array}$ \\
\hline $\begin{array}{l}\text { All individuals } \\
\text { Never married }\end{array}$ & $53 \%$ & $49 \%$ & $46 \%$ & $46 \%$ & $45 \%$ & $40 \%$ & $40 \%$ \\
$\quad$ & & & & & & & \\
$\quad$ Men & 47 & 45 & 44 & 43 & 45 & 43 & 41 \\
$\quad$ Women & 52 & 49 & 44 & 44 & 47 & 38 & 39 \\
Currently married & & & & & & & \\
$\quad$ Men & 39 & 39 & 37 & 39 & 38 & 35 & 35 \\
$\quad$ Women & 78 & 68 & 57 & 52 & 49 & 44 & 44 \\
Widowed & & & & & & & \\
$\quad$ Men & 41 & 40 & 40 & 42 & 38 & 37 & 41 \\
$\quad$ Women & 121 & 86 & 81 & 70 & 66 & 58 & 58 \\
Divorced & & & & & & & \\
$\quad$ Men & 44 & 43 & 40 & 41 & 41 & 37 & 36 \\
$\quad$ Women & 66 & 57 & 53 & 52 & 50 & 46 & 44 \\
\hline
\end{tabular}

Note: Replacement rate is defined as the unit's Social Security benefit over AIME.

Source: Authors' calculations based on MINT. 
Table 6. Estimated Replacement Rates, Household Level (Median), MINT by Birth Cohort

\begin{tabular}{lccccccc}
\hline & $\begin{array}{c}\text { Depression } \\
\text { 1931-1935 }\end{array}$ & $\begin{array}{c}\text { Depression } \\
\text { 1936-1941 }\end{array}$ & War Baby & $\begin{array}{c}\text { Early } \\
\text { Boomers }\end{array}$ & $\begin{array}{c}\text { Middle } \\
\text { Boomers }\end{array}$ & $\begin{array}{c}\text { Late } \\
\text { Boomers }\end{array}$ & $\begin{array}{c}\text { Generation } \\
\text { Xers }\end{array}$ \\
\hline All households & $50 \%$ & $47 \%$ & $45 \%$ & $45 \%$ & $44 \%$ & $39 \%$ & $39 \%$ \\
Never married & 47 & 47 & 43 & 44 & 45 & 40 & 38 \\
Currently married & & & & & & & 39 \\
$\quad$ Single-earner & 53 & 54 & 54 & 54 & 48 & 38 \\
$\quad$ Two-earner & 45 & 43 & 41 & 41 & 40 & 36 & 37 \\
$\quad$ Combined & 47 & 45 & 42 & 42 & 41 & 37 & 37 \\
Widowed & 64 & 60 & 61 & 56 & 53 & 48 & 50 \\
Divorced & 52 & 48 & 46 & 47 & 45 & 41 & 40 \\
\hline
\end{tabular}

Note: Replacement rate is defined as the unit's Social Security benefit over AIME.

Source: Authors' calculations based on MINT. 
Table 7. Characteristics for Individuals When First Claimed Benefits, MINT by Birth Cohort

\begin{tabular}{|c|c|c|c|c|c|c|c|}
\hline & $\begin{array}{l}\text { Depression } \\
1931-1935 \\
\end{array}$ & $\begin{array}{l}\text { Depression } \\
1936-1941 \\
\end{array}$ & War Baby & $\begin{array}{c}\text { Early } \\
\text { Boomers }\end{array}$ & $\begin{array}{c}\text { Middle } \\
\text { Boomers }\end{array}$ & $\begin{array}{c}\text { Late } \\
\text { Boomers }\end{array}$ & $\begin{array}{c}\text { Generation } \\
\text { Xers } \\
\end{array}$ \\
\hline \multicolumn{8}{|l|}{ Gender } \\
\hline Men & $46.76 \%$ & $47.18 \%$ & $47.14 \%$ & $46.20 \%$ & $46.87 \%$ & $47.44 \%$ & $47.58 \%$ \\
\hline Women & 53.24 & 52.82 & 52.86 & 53.80 & 53.13 & 52.56 & 52.42 \\
\hline \multicolumn{8}{|l|}{ Marital status } \\
\hline Married & $73.76 \%$ & $72.12 \%$ & $68.05 \%$ & $63.35 \%$ & $61.08 \%$ & $60.52 \%$ & $58.53 \%$ \\
\hline Divorced & 10.62 & 12.85 & 17.55 & 19.39 & 20.13 & 20.25 & 20.97 \\
\hline Never married & 3.53 & 3.82 & 4.79 & 6.47 & 7.65 & 8.23 & 10.31 \\
\hline Widowed & 12.09 & 11.20 & 9.61 & 10.78 & 11.14 & 11.00 & 10.19 \\
\hline \multicolumn{8}{|l|}{ Education } \\
\hline Less than high school & $20.59 \%$ & $13.92 \%$ & $9.04 \%$ & $6.37 \%$ & $7.32 \%$ & $7.19 \%$ & $8.10 \%$ \\
\hline High school & 58.84 & 61.58 & 59.76 & 58.23 & 60.32 & 59.04 & 54.56 \\
\hline College + & 20.58 & 24.50 & 31.20 & 35.40 & 32.36 & 33.77 & 37.34 \\
\hline \multicolumn{8}{|c|}{ Average numbers of covered quarters } \\
\hline \multicolumn{8}{|c|}{ Men } \\
\hline Married & 141 & 143 & 144 & 143 & 144 & 146 & 142 \\
\hline Divorced & 137 & 135 & 142 & 139 & 144 & 148 & 147 \\
\hline Never married & 127 & 132 & 131 & 136 & 133 & 135 & 140 \\
\hline Widowed & 139 & 141 & 134 & 137 & 141 & 141 & 137 \\
\hline \multicolumn{8}{|l|}{ Women } \\
\hline Married & 75 & 86 & 99 & 110 & 117 & 119 & 120 \\
\hline Divorced & 106 & 107 & 121 & 129 & 131 & 131 & 129 \\
\hline Never married & 124 & 132 & 132 & 142 & 134 & 140 & 137 \\
\hline Widowed & 84 & 92 & 106 & 113 & 116 & 119 & 117 \\
\hline \multicolumn{8}{|l|}{ Benefit type (all women) } \\
\hline Retired worker & $44.20 \%$ & $55.30 \%$ & $59.47 \%$ & $67.91 \%$ & $70.50 \%$ & $71.77 \%$ & $75.17 \%$ \\
\hline Dually entitled & 31.31 & 28.34 & 27.91 & 23.92 & 21.62 & 20.57 & 17.73 \\
\hline Auxiliary only & 24.50 & 16.35 & 12.62 & 8.16 & 7.87 & 7.66 & 7.10 \\
\hline
\end{tabular}


Table 7 (con't). Characteristics for Individuals When First Claimed Benefits, MINT by Birth Cohort

\begin{tabular}{|c|c|c|c|c|c|c|c|}
\hline & $\begin{array}{l}\text { Depression } \\
1931-1935 \\
\end{array}$ & $\begin{array}{l}\text { Depression } \\
1936-1941 \\
\end{array}$ & War Baby & $\begin{array}{c}\text { Early } \\
\text { Boomers }\end{array}$ & $\begin{array}{c}\text { Middle } \\
\text { Boomers }\end{array}$ & $\begin{array}{c}\text { Late } \\
\text { Boomers }\end{array}$ & $\begin{array}{c}\text { Generation } \\
\text { Xers }\end{array}$ \\
\hline \multicolumn{8}{|c|}{ Average AIME (household level) 2012 dollars } \\
\hline Married & $\$ 48,474$ & $\$ 58,188$ & $\$ 69,901$ & $\$ 77,339$ & $\$ 84,564$ & $\$ 90,867$ & $\$ 96,205$ \\
\hline Divorced & $\$ 24,499$ & $\$ 28,366$ & $\$ 35,004$ & $\$ 36,661$ & $\$ 41,158$ & $\$ 44,629$ & $\$ 49,003$ \\
\hline Never married & $\$ 25,829$ & $\$ 31,681$ & $\$ 37,679$ & $\$ 40,096$ & $\$ 40,939$ & $\$ 43,625$ & $\$ 51,373$ \\
\hline Widowed & $\$ 21,491$ & $\$ 25,465$ & $\$ 29,014$ & $\$ 32,608$ & $\$ 36,855$ & $\$ 39,889$ & $\$ 40,475$ \\
\hline \multicolumn{8}{|c|}{ Average Benefit (household level) 2012 dollars } \\
\hline Married & $\$ 22,126$ & $\$ 25,536$ & $\$ 28,888$ & $\$ 31,400$ & $\$ 33,225$ & $\$ 32,046$ & $\$ 33,647$ \\
\hline Divorced & $\$ 12,397$ & $\$ 13,012$ & $\$ 15,620$ & $\$ 16,360$ & $\$ 17,543$ & $\$ 17,063$ & $\$ 18,148$ \\
\hline Never married & $\$ 11,290$ & $\$ 13,533$ & $\$ 14,908$ & $\$ 16,043$ & $\$ 16,260$ & $\$ 15,209$ & $\$ 17,291$ \\
\hline Widowed & $\$ 13,264$ & $\$ 14,439$ & $\$ 16,062$ & $\$ 17,004$ & $\$ 18,300$ & $\$ 17,606$ & $\$ 18,353$ \\
\hline \multicolumn{8}{|l|}{ Actual claiming age } \\
\hline All & 63.5 & 63.4 & 63.9 & 64.3 & 64.1 & 64.1 & 64.1 \\
\hline Men & 63.9 & 63.7 & 64.0 & 64.5 & 64.3 & 64.4 & 64.4 \\
\hline Women & 63.3 & 63.2 & 63.7 & 64.1 & 63.9 & 63.8 & 63.8 \\
\hline
\end{tabular}

Source: Authors' calculations based on MINT. 
Table 8.1. Estimated Replacement Rates for the Married (Median, Single-Earner Households), MINT by Birth Cohort

\begin{tabular}{cccccccc}
\hline & $\begin{array}{c}\text { Depression } \\
\text { 1931-1935 }\end{array}$ & $\begin{array}{c}\text { Depression } \\
1936-1941\end{array}$ & War Baby & $\begin{array}{c}\text { Early } \\
\text { Boomers }\end{array}$ & $\begin{array}{c}\text { Middle } \\
\text { Boomers }\end{array}$ & $\begin{array}{c}\text { Late } \\
\text { Boomers }\end{array}$ & $\begin{array}{c}\text { Generation } \\
\text { Xers }\end{array}$ \\
\hline Husband's earnings & & & & & & & \\
Low & $73 \%$ & $72 \%$ & $67 \%$ & $72 \%$ & $52 \%$ & $54 \%$ & $55 \%$ \\
Median & 53 & 52 & 48 & 46 & 44 & 31 & 34 \\
High & 46 & 44 & 46 & 37 & 42 & 33 & 26 \\
\hline
\end{tabular}

Table 8.2. Estimated Replacement Rates for the Married (Median, Two-Earner Households), MINT by Birth Cohort

\begin{tabular}{lccccccc}
\hline & $\begin{array}{c}\text { Depression } \\
\text { 1931-1935 }\end{array}$ & $\begin{array}{c}\text { Depression } \\
\text { 1936-1941 }\end{array}$ & War Baby & $\begin{array}{c}\text { Early } \\
\text { Boomers }\end{array}$ & $\begin{array}{c}\text { Middle } \\
\text { Boomers }\end{array}$ & $\begin{array}{c}\text { Late } \\
\text { Boomers }\end{array}$ & $\begin{array}{c}\text { Generation } \\
\text { Xers }\end{array}$ \\
\hline Husband's earnings & & & & & & & \\
Low & $53 \%$ & $53 \%$ & $51 \%$ & $51 \%$ & $49 \%$ & $44 \%$ & $46 \%$ \\
Median & 45 & 43 & 40 & 42 & 41 & 36 & 38 \\
High & 41 & 38 & 37 & 36 & 36 & 31 & 30 \\
\hline
\end{tabular}

Table 8.3. Estimated Replacement Rates for the Married (Median, Combined), MINT by Birth Cohort

\begin{tabular}{|c|c|c|c|c|c|c|c|}
\hline & $\begin{array}{r}\text { Depression } \\
1931-1935 \\
\end{array}$ & $\begin{array}{l}\text { Depression } \\
1936-1941 \\
\end{array}$ & War Baby & $\begin{array}{c}\text { Early } \\
\text { Boomers }\end{array}$ & $\begin{array}{c}\text { Middle } \\
\text { Boomers }\end{array}$ & $\begin{array}{c}\text { Late } \\
\text { Boomers }\end{array}$ & $\begin{array}{c}\text { Generation } \\
\text { Xers } \\
\end{array}$ \\
\hline \multicolumn{8}{|c|}{ Husband's earnings } \\
\hline Low & $58 \%$ & $57 \%$ & $54 \%$ & $53 \%$ & $50 \%$ & $45 \%$ & $47 \%$ \\
\hline Median & 46 & 44 & 41 & 42 & 41 & 36 & 37 \\
\hline High & 42 & 39 & 37 & 36 & 36 & 31 & 30 \\
\hline
\end{tabular}

Note: Replacement rate is defined as the unit's Social Security benefit over AIME.

Source: Authors' calculations based on MINT. 
Table 9. Explaining Differences over Time, Decomposition, Household Level, All

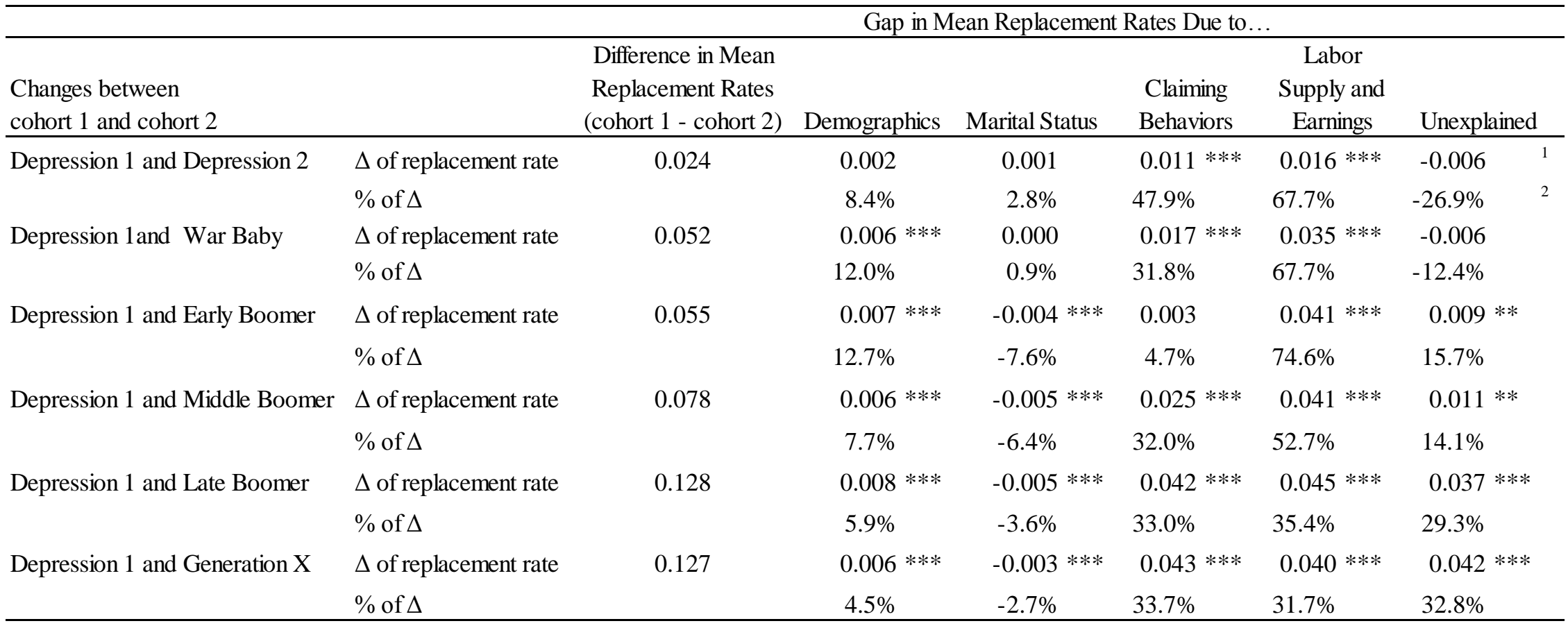

Note: Significance level, $* * * \mathrm{p}<0.01, * * \mathrm{p}<0.05, * \mathrm{p}<0.1$.; Standard errors of the younger cohorts are likely understated, and significance levels overstated as they do not take into account that some of the input data are themselves projected

1. The sum of demographics, marital status, claiming behaviors, labor supply and earnings, and unexplained equals to difference in mean replacement rates.

2. The sum of demographics, marital status, claiming behaviors, labor supply and earnings, and unexplained equals to $100 \%$. Rounding errors are possible.

Source: Authors' calculations based on MINT. 
Table 10. Explaining Differences over Time, Decomposition, Household Level, Women

\begin{tabular}{|c|c|c|c|c|c|c|c|c|}
\hline & & \multicolumn{7}{|c|}{ Gap in Mean Replacement Rates Due to... } \\
\hline \multicolumn{2}{|l|}{$\begin{array}{l}\text { Changes between } \\
\text { cohort } 1 \text { and cohort } 2\end{array}$} & $\begin{array}{l}\text { Difference in Mean } \\
\text { Replacement Rates } \\
\text { (cohort } 1 \text { - cohort 2) }\end{array}$ & Demographics & Marrital Status & $\begin{array}{c}\text { Claiming } \\
\text { Behaviors }\end{array}$ & $\begin{array}{c}\text { Labor Supply } \\
\text { and Earnings }\end{array}$ & Unexplained & \\
\hline \multirow[t]{2}{*}{ Depression 1 and Depression 2} & $\Delta$ of replacement rate & 0.033 & $0.002 * *$ & 0.001 & $0.009 * * *$ & $0.021 * * *$ & -0.001 & 1 \\
\hline & $\%$ of $\Delta$ & & $7.0 \%$ & $3.6 \%$ & $28.0 \%$ & $63.3 \%$ & $-1.8 \%$ & 2 \\
\hline \multirow{2}{*}{ Depression 1 and War Baby } & $\Delta$ of replacement rate & 0.059 & $0.006 * * *$ & 0.002 & $0.011 * * *$ & $0.052 * * *$ & $-0.012 * *$ & \\
\hline & $\%$ of $\Delta$ & & $10.5 \%$ & $3.4 \%$ & $18.1 \%$ & $88.0 \%$ & $-20.0 \%$ & \\
\hline \multirow[t]{2}{*}{ Depression 1 and Early Boomer } & $\Delta$ of replacement rate & 0.070 & $0.006 * *$ & -0.002 & 0.000 & $0.070 * * *$ & -0.005 & \\
\hline & $\%$ of $\Delta$ & & $8.9 \%$ & $-2.2 \%$ & $-0.7 \%$ & $100.9 \%$ & $-6.9 \%$ & \\
\hline \multirow[t]{2}{*}{ Depression 1 and Middle Boomer } & $\Delta$ of replacement rate & 0.090 & $0.007 * * *$ & -0.002 & $0.021 * * *$ & $0.070 * * *$ & -0.006 & \\
\hline & $\%$ of $\Delta$ & & $7.6 \%$ & $-2.7 \%$ & $23.0 \%$ & $78.2 \%$ & $-6.2 \%$ & \\
\hline \multirow[t]{2}{*}{ Depression 1 and Late Boomer } & $\Delta$ of replacement rate & 0.141 & $0.010 * * *$ & -0.003 & $0.040 * * *$ & $0.077 * * *$ & $0.017 * *$ & \\
\hline & $\%$ of $\Delta$ & & $7.3 \%$ & $-2.0 \%$ & $28.1 \%$ & $54.3 \%$ & $12.3 \%$ & \\
\hline \multirow[t]{2}{*}{ Depression 1 and Generation $\mathrm{X}$} & $\Delta$ of replacement rate & 0.142 & $0.009 * * *$ & -0.001 & $0.040 * * *$ & $0.072 * * *$ & $0.022 * * *$ & \\
\hline & $\%$ of $\Delta$ & & $6.1 \%$ & $-0.7 \%$ & $28.5 \%$ & $50.6 \%$ & $15.6 \%$ & \\
\hline
\end{tabular}

Note: Significance level, $* * * \mathrm{p}<0.01, * * \mathrm{p}<0.05, * \mathrm{p}<0.1$; Standard errors of the younger cohorts are likely understated, and significance levels overstated as they do not take into account that some of the input data are themselves projected.

1. The sum of demographics, marital status, claiming behaviors, labor supply and earnings, and unexplained equals to difference in mean replacement rates. 2. The sum of demographics, marital status, claiming behaviors, labor supply and earnings, and unexplained equals to $100 \%$. Rounding errors are possible. Source: Authors' calculations based on MINT. 
Table 11. Explaining Differences over Time, Decomposition, Household Level, by Marital Status

\begin{tabular}{|c|c|c|c|c|c|c|c|c|c|c|}
\hline & & & & & Gap in Me & n Replacement R & Due to... & & & \\
\hline Changes between & & Difference in Mean & & & & & Spouse's & Spouse's & & \\
\hline Depression 1 and & & Replacement Rates & & Claiming & Labor Supply & Spouse's & Claiming & Labor Supply & & \\
\hline Generation X & & (Depression 1 - Gen X) & Demographics & Behaviors & and Earnings & Demographics & Behaviors & and Earnings & Unexplaine & \\
\hline Married & $\Delta$ of replacement rate & 0.112 & 0.000 & $0.026 * * *$ & $0.027 * * *$ & $0.002 * *$ & $0.022 * * *$ & $0.032 * * *$ & 0.001 & 1 \\
\hline & $\%$ of $\Delta$ & & $0.1 \%$ & $23.5 \%$ & $24.4 \%$ & $2.0 \%$ & $20.0 \%$ & $28.2 \%$ & $1.3 \%$ & 2 \\
\hline Widowed & $\Delta$ of replacement rate & 0.177 & 0.004 & $0.049 * * *$ & $0.093 * * *$ & & & & $0.031 * *$ & \\
\hline & $\%$ of $\Delta$ & & $2.1 \%$ & $27.7 \%$ & $52.5 \%$ & & & & $17.7 \%$ & \\
\hline Divorced & $\Delta$ of replacement rate & 0.150 & 0.002 & $0.073 * * *$ & $0.068 * * *$ & & & & 0.007 & \\
\hline & $\%$ of $\Delta$ & & $1.5 \%$ & $48.7 \%$ & $45.0 \%$ & & & & $4.9 \%$ & \\
\hline Never married & $\Delta$ of replacement rate & 0.170 & 0.003 & $0.085 * * *$ & $0.060 * * *$ & & & & $0.022 * *$ & \\
\hline & $\%$ of $\Delta$ & & $1.8 \%$ & $49.8 \%$ & $35.3 \%$ & & & & $13.1 \%$ & \\
\hline
\end{tabular}

Note: Significance level, $* * * \mathrm{p}<0.01, * * \mathrm{p}<0.05, * \mathrm{p}<0.1$; Standard errors of the younger cohorts are likely understated, and significance levels overstated as they do not take into account that some of the input data are themselves projected

1. The sum of demographics, claiming behaviors, labor supply, spouse's demographics, spouse's claiming behaviors, spouse's labor supply and earnings and unexplained equals to difference in mean replacement rates.

2. The sum of demographics, claiming behaviors, labor supply, spouse's demographics, spouse's claiming behaviors, spouse's labor supply and earnings and unexplained equals to $100 \%$. Rounding errors are possible.

Source: Authors' calculations based on MINT. 
Table 12. Comparison of Replacement Rates: Actual Claiming Age vs. Claiming at FRA, Household Level (Median), MINT by Birth Cohort

\begin{tabular}{|c|c|c|c|c|c|c|c|}
\hline & $\begin{array}{l}\text { Depression } \\
1931-1935 \\
\end{array}$ & $\begin{array}{l}\text { Depression } \\
1936-1941 \\
\end{array}$ & War Baby & $\begin{array}{c}\text { Early } \\
\text { Boomers }\end{array}$ & $\begin{array}{c}\text { Middle } \\
\text { Boomers }\end{array}$ & $\begin{array}{c}\text { Late } \\
\text { Boomers }\end{array}$ & $\begin{array}{c}\text { Generation } \\
\text { Xers }\end{array}$ \\
\hline \multicolumn{8}{|l|}{ All households } \\
\hline Actual claiming age & $50 \%$ & $47 \%$ & $45 \%$ & $45 \%$ & $44 \%$ & $39 \%$ & $39 \%$ \\
\hline Claiming at FRA & 55 & 53 & 51 & 51 & 51 & 49 & 49 \\
\hline \multicolumn{8}{|l|}{ Never married } \\
\hline Actual claiming age & 47 & 47 & 43 & 44 & 45 & 40 & 38 \\
\hline Claiming at FRA & 53 & 50 & 49 & 48 & 52 & 51 & 49 \\
\hline \multicolumn{8}{|l|}{ Currently married } \\
\hline Actual claiming age & 47 & 45 & 42 & 42 & 41 & 37 & 37 \\
\hline Claiming at FRA & 53 & 51 & 48 & 48 & 48 & 45 & 46 \\
\hline \multicolumn{8}{|l|}{ Widowed } \\
\hline Actual claiming age & 64 & 60 & 61 & 56 & 53 & 48 & 50 \\
\hline Claiming at FRA & 77 & 70 & 70 & 64 & 63 & 62 & 63 \\
\hline \multicolumn{8}{|l|}{ Divorced } \\
\hline Actual claiming age & 52 & 48 & 46 & 47 & 45 & 41 & 40 \\
\hline Claiming at FRA & 55 & 53 & 52 & 53 & 52 & 51 & 50 \\
\hline
\end{tabular}

Note: Replacement rate is defined as the unit's Social Security benefit over AIME.

Source: Authors' calculations based on MINT. 
Table 13. Explaining Differences over Time, Decomposition of Mean Differences in Replacement Rates at FRA, Household Level, All

\begin{tabular}{|c|c|c|c|c|c|c|c|}
\hline & & & \multicolumn{5}{|c|}{ Gap in Mean Replacement Rates Due to... } \\
\hline $\begin{array}{l}\text { Changes between } \\
\text { cohort } 1 \text { and cohort } 2\end{array}$ & & $\begin{array}{l}\text { Difference in Mean } \\
\text { Replacement Rates } \\
\text { (cohort } 1 \text { - cohort 2) }\end{array}$ & Demographics & Marital Status & $\begin{array}{l}\text { Labor Supply } \\
\text { and Earnings }\end{array}$ & Unexplained & \\
\hline \multirow[t]{2}{*}{ Depression 1 and Depression 2} & $\Delta$ of replacement rate & 0.017 & 0.002 & 0.001 & $0.018 * * *$ & -0.004 & 1 \\
\hline & $\%$ of $\Delta$ & & $12.2 \%$ & $4.3 \%$ & $105.7 \%$ & $-23.8 \%$ & 2 \\
\hline \multirow[t]{2}{*}{ Depression 1 and War Baby } & $\Delta$ of replacement rate & 0.044 & $0.006 * * *$ & 0.001 & $0.039 * * *$ & -0.002 & \\
\hline & $\%$ of $\Delta$ & & $14.8 \%$ & $1.4 \%$ & $88.1 \%$ & $-4.6 \%$ & \\
\hline \multirow[t]{2}{*}{ Depression 1 and Early Boomer } & $\Delta$ of replacement rate & 0.059 & $0.007 * * *$ & $-0.005 * * *$ & $0.046 * * *$ & $0.011 * *$ & \\
\hline & $\%$ of $\Delta$ & & $11.7 \%$ & $-8.6 \%$ & $77.5 \%$ & $19.3 \%$ & \\
\hline \multirow[t]{2}{*}{ Depression 1 and Middle Boomer } & $\Delta$ of replacement rate & 0.066 & $0.006 * * *$ & $-0.006 * * *$ & $0.047 * * *$ & $0.019 * * *$ & \\
\hline & $\%$ of $\Delta$ & & $8.5 \%$ & $-9.5 \%$ & $72.0 \%$ & $29.0 \%$ & \\
\hline \multirow[t]{2}{*}{ Depression 1 and Late Boomer } & $\Delta$ of replacement rate & 0.102 & $0.008 * * *$ & $-0.006 * * *$ & $0.053 * * *$ & $0.048 * * *$ & \\
\hline & $\%$ of $\Delta$ & & $7.9 \%$ & $-6.2 \%$ & $51.7 \%$ & $46.5 \%$ & \\
\hline Depression 1 and Generation $\mathrm{X}$ & $\begin{array}{l}\Delta \text { of replacement rate } \\
\% \text { of } \Delta\end{array}$ & 0.100 & $\begin{array}{l}0.006 * * * \\
6.2 \%\end{array}$ & $\begin{array}{l}-0.005 * * * \\
-5.2 \%\end{array}$ & $\begin{array}{l}0.050 * * * \\
50.1 \%\end{array}$ & $\begin{array}{l}0.049 * * * \\
48.9 \%\end{array}$ & \\
\hline
\end{tabular}

Note: Significance level, $* * * \mathrm{p}<0.01, * * \mathrm{p}<0.05, * \mathrm{p}<0.1$.; Standard errors of the younger cohorts are likely understated, and significance levels overstated as they do not take into account that some of the input data are themselves projected.

1. The sum of demographics, marital status, labor supply and earnings, and unexplained equals to difference in mean replacement rates.

2. The sum of demographics, marital status, labor supply and earnings, and unexplained equals to $100 \%$. Rounding errors are possible.

Source: Authors' calculations based on MINT. 
Table 14. Explaining Differences over Time, Decomposition of Mean Differences in Replacement Rates at FRA, Household Level, Women

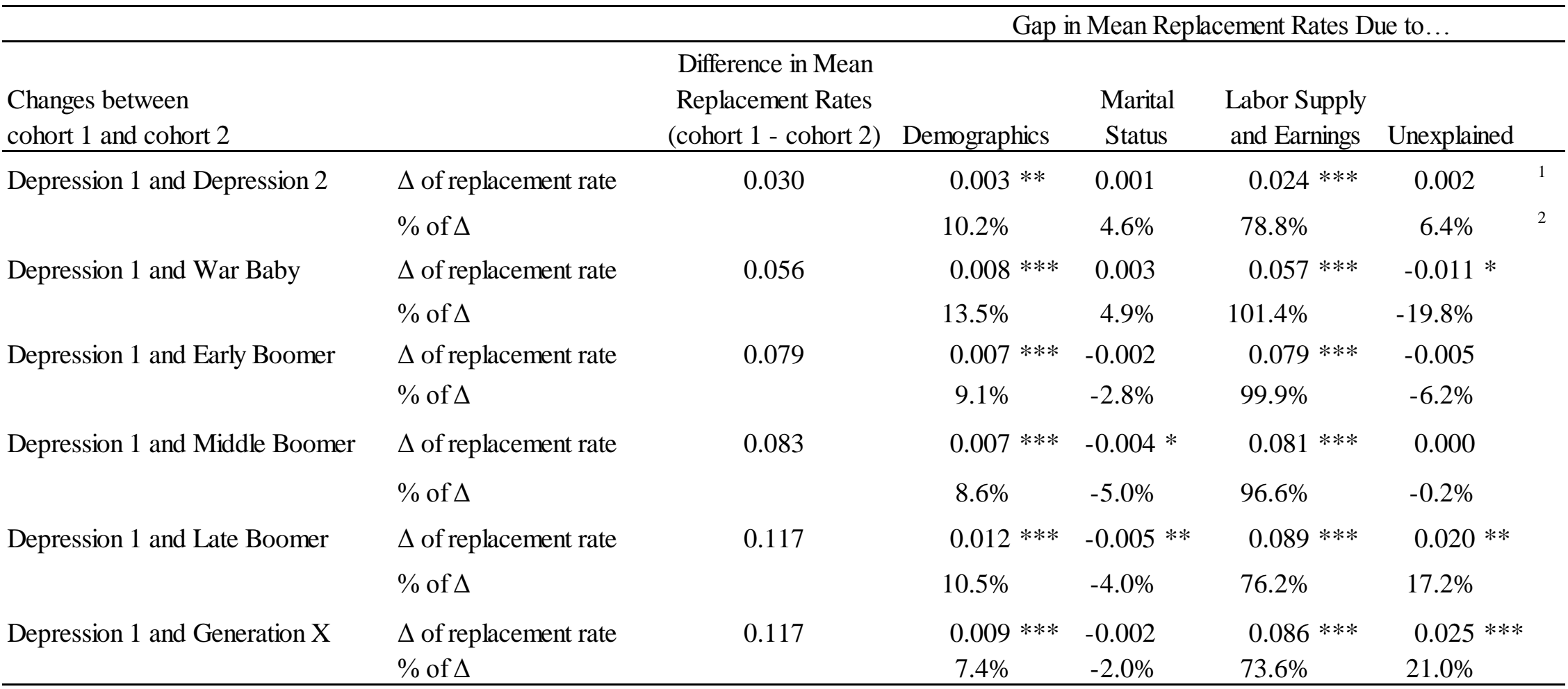

Note Significance level, $* * * \mathrm{p}<0.01, * * \mathrm{p}<0.05, * \mathrm{p}<0.1$. ; Standard errors of the younger cohorts are likely understated, and significance levels overstated as they do not take into account that some of the input data are themselves projected

1. The sum of demographics, marital status, labor supply and earnings, and unexplained equals to difference in mean replacement rates.

2. The sum of demographics, marital status, labor supply and earnings, and unexplained equals to $100 \%$. Rounding errors are possible.

Source: Authors' calculations based on MINT. 
Table 15. Explaining Differences over Time, Decomposition of Mean Replacement Rates at FRA, by Marital Status

\begin{tabular}{|c|c|c|c|c|c|c|c|}
\hline & & & & Gap in Mea & n Replacement I & ites Due to... & \\
\hline Changes between & & Difference in Mean & & Labor & & Spouse's Labor & \\
\hline & $\%$ of $\Delta$ & & $-1.9 \%$ & $38.3 \%$ & $2.0 \%$ & $43.4 \%$ & $18.3 \%$ \\
\hline Widowed & $\Delta$ of replacement rate & 0.165 & 0.004 & $0.111 * * *$ & & & $0.051 * *$ \\
\hline & $\%$ of $\Delta$ & & $-0.2 \%$ & $72.2 \%$ & & & $28.0 \%$ \\
\hline Never married & $\Delta$ of replacement rate & 0.110 & 0.005 & $0.070 * * *$ & & & $0.035 * *$ \\
\hline & $\%$ of $\Delta$ & & $4.1 \%$ & $63.9 \%$ & & & $32.0 \%$ \\
\hline
\end{tabular}

Note: Significance level, *** $\mathrm{p}<0.01, * * \mathrm{p}<0.05, * \mathrm{p}<0.1$; Standard errors of the younger cohorts are likely understated, and significance levels overstated as they do not take into account that some of the input data are themselves projected

1. The sum of demographics, labor supply, spouse's demographics, spouse's labor supply and earnings, and unexplained equals to difference in mean replacement rates.

2. The sum of demographics, labor supply, spouse's demographics, spouse's labor supply and earnings, and unexplained equals to $100 \%$. Rounding errors are possible.

Source: Authors' calculations based on MINT. 


\section{RECENT WORKING PAPERS FROM THE CENTER FOR RETIREMENT RESEARCH AT BOSTON COLLEGE}

Social Security and the 2001 Reform of the Railroad Retirement Program Steven A. Sass, June 2013

An Assessment of the 2001 Reform of the Railroad Retirement Program Steven A. Sass, June 2013

Reforming the Railroad Retirement System Steven A. Sass, June 2013

How Do the Disabled Cope While Waiting for SSDI?

Norma B. Coe, Stephan Lindner, Kendrew Wong, and April Yanyuan Wu, June 2013

The Impact of Population Aging and Delayed Retirement on Workforce Productivity Gary Burtless, May 2013

Does Access to Health Insurance Influence Work Effort Among Disability Cash Benefit Recipients?

Norma B. Coe and Kalman Rupp, April 2013

How Will Older Workers Who Lose Their Jobs During the Great Recession Fare in the Long-Run?

Matthew S. Rutledge, Natalia Orlova, and Anthony Webb, March 2013

Can Long-Term Care Insurance Partnership Programs Increase Coverage and Reduce Medicaid Costs?

Wei Sun and Anthony Webb, March 2013

SSI for Disabled Immigrants: Why Do Ethnic Networks Matter?

Delia Furtado and Nikolaos Theodoropoulos, February 2013

The Use of VA Disability Benefits and Social Security Disability Insurance Among Veterans

Janet M. Wilmoth, Andrew S. London, and Colleen M. Heflin, February 2013

How Does the Composition of Disability Insurance Applicants Change Across Business Cycles?

Norma B. Coe and Matthew S. Rutledge, February 2013

All working papers are available on the Center for Retirement Research website (http://crr.bc.edu) and can be requested by e-mail (crr@bc.edu) or phone (617-552-1762). 